\title{
Asia's little divergence: state capacity in China and Japan before 1850
}

\author{
Tuan-Hwee Sng • Chiaki Moriguchi
}

Published online: 12 September 2014

C) Springer Science+Business Media New York 2014

\begin{abstract}
This paper explores the role of state capacity in the comparative economic development of China and Japan. Before 1850, both nations were ruled by stable dictators who relied on bureaucrats to govern their domains. We hypothesize that agency problems increase with the geographical size of a domain. In a large domain, the ruler's inability to closely monitor bureaucrats creates opportunities for the bureaucrats to exploit taxpayers. To prevent overexploitation, the ruler has to keep taxes low and government small. Our dynamic model shows that while economic expansion improves the ruler's finances in a small domain, it could lead to lower tax revenues in a large domain as it exacerbates bureaucratic expropriation. To check these implications, we assemble comparable quantitative data from primary and secondary sources. We find that the state taxed less and provided fewer local public goods per capita in China than in Japan. Furthermore, while the Tokugawa shogunate's tax revenue grew in tandem with demographic trends, Qing China underwent fiscal contraction after 1750 despite demographic expansion. We conjecture that a greater state capacity might have prepared Japan better for the transition from stagnation to growth.
\end{abstract}

Keywords Comparative institutional analysis · Geography · Principal-agent problem · Institutions and growth

JEL Classification $\quad \mathrm{D} 73 \cdot \mathrm{N} 15 \cdot \mathrm{N} 40 \cdot \mathrm{O} 43 \cdot \mathrm{P} 52$

\section{Introduction}

Why was Japan the first non-Western nation to industrialize? Why did China take longer to modernize? At first glance, China's later industrialization appears puzzling. Unified growth

T.-H. Sng $(\bowtie)$

Department of Economics, National University of Singapore, Singapore, Singapore

e-mail: tsng@nus.edu.sg

C. Moriguchi

Institute of Economic Research, Hitotsubashi University, Tokyo, Japan

e-mail: chiaki@ier.hit-u.ac.jp 
theory suggests that the transition from stagnation to growth is driven by the positive interaction between population expansion and technological progress and its impact on the demand for human capital and the onset of the demographic transition (Galor 2005, 2011). All else equal, China, one of the most technologically advanced and certainly the most populous nation in the world throughout most of history, should be an early industrializer. While differences in geographical endowment, institutions, culture, and diversity could help explain the Great Divergence between China and Europe (Jones 1981; Landes 1998; Pomeranz 2000; Ashraf and Galor 2013), these differences seem unsatisfactory in explaining the economic divergence between China and Japan.

Traditional accounts typically attribute Japan's earlier industrialization to the Meiji Restoration. According to this view, Qing China (1644-1911) and Tokugawa Japan (16001868 ) were both governed by despotic rulers who were uninterested in promoting economic growth. ${ }^{1}$ Their paths diverged only after 1868 , when the Tokugawa regime was overthrown and the new Meiji government introduced drastic reforms that transformed Japan. As Beasley (1972) put it,

During the middle decades of the nineteenth century China and Japan both faced pressure from an intrusive, expanding West. ... Emotionally and intellectually, Chinese and Japanese reacted to the threat in similar ways. ... Yet they differed greatly in the kind of actions that this response induced. ... The Meiji Restoration is at the heart of this contrast, since it was the process by which Japan acquired a leadership committed to reform and able to enforce it. For Japan, therefore, the Restoration has something of the significance that the English Revolution has for England or the French Revolution for France; it is the point from which modern history can be said to begin.

Recent reassessments have put the Chinese and Japanese economies on the eve of the modern age in better standing. It has been shown that, like Western Europe, China and Japan experienced widespread commercialization and proto-industrialization during the early modern period (Pomeranz 2000). However, the revisionist view, too, tends to play down the differences between pre-1850 China and Japan, and focus instead on their similarities (Pomeranz 2000; He 2013).

Indeed, early modern China and Japan had much in common. Both depended heavily on small-scale, labor-intensive, and rice-based agriculture. Both were ruled by stable and sophisticated governments long before the arrival of the West. Furthermore, they shared a common cultural, institutional, and technological heritage. As a result of active cultural borrowing from China, Tokugawa Japan was also deeply influenced by Confucianism. Chinese administrative codes played an important role in shaping the way that the Tokugawa shogunate was run (Jansen 1992). Existing evidence suggests that living standards in China and Japan were comparable during this period (Maddison 2001; Baten et al. 2010; Allen et al. 2011; Broadberry 2013). ${ }^{2}$

We point to an important empirical observation that fits neither traditional nor revisionist perspectives, however. As Figure 1 illustrates, from 1650 to 1850, tax revenue per capita was

\footnotetext{
${ }^{1}$ See, for example, Wittfogel (1957) and Balazs (1964) on China; Alcock (1863) and Reischauer (1970) on Japan.

2 Most of these studies show that living standards in China and Japan were low and stable from 1700 to 1850. The exception is Broadberry (2013), who shows a declining GDP per capita in China. Our findings below are qualitatively the same regardless of which set of estimates we use. If we use Broadberry's estimates, the Tokugawa shogunate's tax-to-GDP ratio would be 1.6 times higher than China's in 1700 and 3.9 times higher by 1850 .
} 


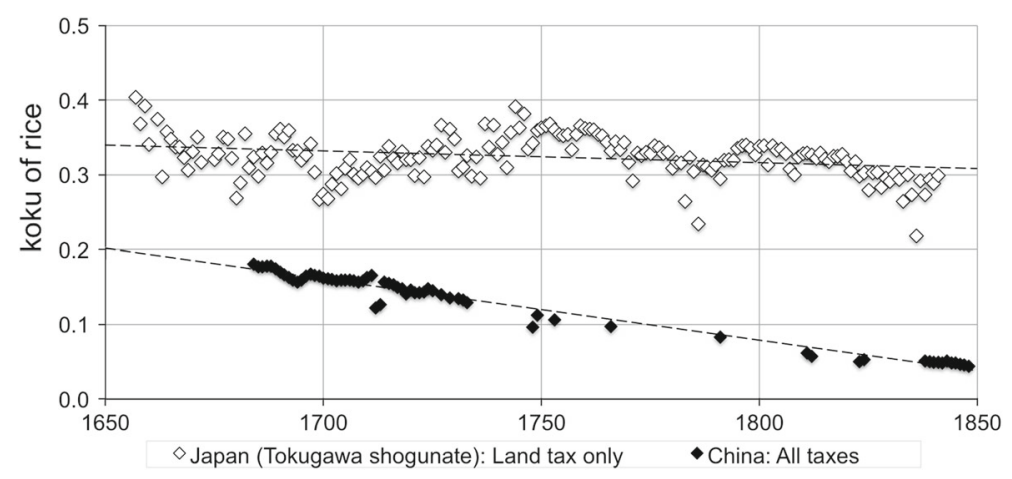

Fig. 1 Per Capita Tax Revenue in China and Japan. Sources: Shogunate's land tax from Ohno (1996); Japan's population estimates from Hayami and Miyamoto (1988); China's tax revenues from Sng (2014); China's population estimates from Perkins (1969)

significantly higher in Tokugawa Japan than in Qing China, and the gap widened over time. ${ }^{3}$ In our estimates, the Chinese state's annual revenue on the eve of the Opium War (18391842) was equivalent to $2 \%$ of its national income at the maximum, while the comparable number for the Tokugawa shogunate was more than $15 \%{ }^{4}$

What were the reasons for these diverging revenue trends? The existing literature offers two hypotheses for China's low tax revenue in general: the absence of warfare and the ideology of benevolence. Economic historians have shown that warfare was a major driver for European states to expand fiscal capacity (Hoffman and Rosenthal 1997; O'Brien 2005; Dincecco et al. 2011; Gennaioli and Voth 2011). In this view, the absence of interstate competition in China and the resulting low fiscal demand were the primary reasons for low taxation in China (Rosenthal and Wong 2011). Alternatively, China historians have argued that low taxation was mainly a reflection of the Confucian ideology of "benevolent rule" (Elliott 2009; Rowe 2009). However, neither of these hypotheses can fully explain the diverging trends in China and Japan because Tokugawa Japan, too, experienced no interstate competition and shared the Confucian ideology of benevolence. ${ }^{5}$ If anything, the European experience suggests that China, not Japan, should have developed a higher fiscal capacity because it was exposed to military threats from Inner Asia.

\footnotetext{
3 Japanese estimates in Fig. 1 are for the domain of the Tokugawa shogun only. Per capita tax revenues for other local lords in Japan were generally higher (see Sect. 4.2). For the shogunate's tax revenue, we include only the land tax to provide a lower bound estimate. For the shogunate's population, we assume $15 \%$ of the Japanese population lived in the shogunate domain throughout this period. For China's tax revenue, we include not only the land tax but also the salt tax, customs duties, and miscellaneous taxes to provide an upper bound estimate. We convert per capita tax revenues in both regimes into koku of rice (180.4 liters of rice), defined historically in Japan as the amount necessary to feed an adult man for a year. We did not include corvée levies, which were effectively phased out in Qing China but were maintained in Tokugawa Japan. Therefore, the actual difference in per capita tax revenue between China and Japan is likely to be bigger than what Fig. 1 suggests.

${ }^{4}$ We assume an annual subsistence consumption of 345 liters of grain per capita in both China and Japan (Huang 2003, p. 158). Multiplying this by population produces lower bound estimates of national income, which in turn generate the upper bound estimates for the ratio of tax revenue to national income presented above.

5 One may also hypothesize that inflation caused by the inflow of silver (Wang 1992) was the reason for China's declining tax revenue. The inflation hypothesis, however, cannot explain why the tax revenue also fell in periods of deflation. See Sng (2014) for further discussion.
} 
In this paper we focus on geography as a primary factor. China was a sprawling land empire with vast inner frontiers, while Japan was a small island nation. We propose that the difference in their geographical size and heterogeneity led to a much more acute problem of political control in the former than in the latter. ${ }^{6}$ In pursuing our research, we follow the methodology of comparative and historical institutional analysis proposed by Greif (1998). That is, we first develop a context-specific model based on historical details to theoretically examine the nature of the problems that the rulers in China and Japan faced and then check its implications using comparative historical evidence.

Between 1650 and 1850, both nations were ruled by stable dictatorships. Following Olson (1993), we model stable dictators as "stationary bandits" who understand that excessive exaction in the short run would be counterproductive in the long run. ${ }^{7}$ However, the ruler's encompassing interest is by itself insufficient to guarantee good governance. Because dictators cannot rule alone and have to rely on agents to govern, a principal-agent problem is inherent in dictatorships. ${ }^{8}$ Unless the interests of the ruler and the agents are well-aligned, in the absence of perfect monitoring, the agents tend to pursue their self-interest at the ruler's expense. For example, they may extort the taxpayers and thereby increase the likelihood of rebellion.

We hypothesize that in a stable dictatorship, agency problems increase with its geographical size and heterogeneity. Given premodern information technologies, it is costly for the ruler of a large domain to monitor the agents closely. This gives the agents strong incentives to extort the taxpayers. To prevent overexploitation that could foment rebellion, the ruler has to keep taxes low and government small. By contrast, in a smaller domain, lower monitoring costs allow the ruler to impose heavier taxes without risking popular resistance.

If the sole purpose of taxation is to support the consumption of the ruling class, whether it enriches the ruler or his agents will not matter to the taxpayers. However, unlike corruption, taxation is rarely a pure rent-seeking activity. The ruler, as the owner of his domain, may use the tax receipts to invest in public goods to keep his property productive. If so, the competition between the ruler and the agents over the economic surplus may have an impact on social welfare, especially in the long run.

To formalize our hypothesis, we build a dynamic principal-agent model and analyze optimal taxation and public goods provision in a stable dictatorship. The ruler taxes the peasants through agents and invests part of the tax revenue in a local public good that protects the economy from exogenous shocks (e.g., natural disasters). If the ruler under-invests in the public good, the risk of a large shock destroying the economy increases.

The static predictions of the model are straightforward: holding monitoring technology constant, as the geographical size of the ruler's domain increases, bureaucratic expropriation worsens and per capita tax revenue falls due to managerial diseconomies of scale.

New insights come from the dynamic implications. While one may expect economic expansion to generate more tax revenues and higher public good investments, this is not always the case. The model predicts that economic expansion could actually hurt the ruler

\footnotetext{
6 We do not claim that geography is the only determinant of state capacity (defined as the ability of the state to raise taxes and provide public goods), as other factors such as governance structure, culture, and technology also influence state capacity. The aim of this study is to isolate the impact of geography on state capacity by holding these factors "constant," taking advantage of the institutional, cultural, and technological similarities between premodern China and Japan.

7 In contrast, unstable dictators behave like "roving bandits" due to their short time horizons.

8 In Levi's words (1988, p. 14), "Absolute monarchs are rulers who possess a virtual monopoly over coercive capacity but not necessarily a perfect monitoring capacity.” See Kiser and Tong (1992), Ma (2011), and Sng (2014) for more discussions on agency problems in imperial China.
} 
because it also exacerbates agency problems. When monitoring cost is sufficiently high, bureaucratic expropriation will outpace economic expansion. It is only when monitoring cost is low that economic change is likely to bring net benefits to the ruler as well as the population.

Our model provides a potential explanation for the tax revenue dynamics in China and Japan documented in Fig. 1. To further check its implications, we examine the provision of local public goods (coinage, transportation network, urban management, forest protection, famine relief) in the two regimes. In line with the model's prediction, we find that, compared to the Chinese emperor, the Tokugawa shogun displayed a greater capability to provide these public goods over a longer period of time.

We take the size of domains in China and Japan as exogenous in our analysis. Given the high agency costs, one may ask if China's vast size was ever optimal. In a broader framework, such as Alesina and Spolaore (1997), the ruler determines the size of his domain by balancing the accompanying costs and benefits, where agency costs are just one such factor. In the case of China, we conjecture that the benefits of political integration-peace and risk sharing among contiguous regions - outweighed high agency costs, thereby justifying its size. We do not model this, however, to keep the scope of our analysis manageable. ${ }^{9}$

To our knowledge, this study is the first comparative analysis of state capacity in preindustrial Asia. ${ }^{10}$ The European experience indicates that most states had a strong fiscal system in place before industrializing (Dincecco 2011; Johnson and Koyama 2014a, b). Indeed, there is a growing body of theoretical and empirical research highlighting the importance of state capacity in facilitating modern economic growth (Acemoglu 2005; Besley and Persson 2009, 2013; Dincecco and Prado 2012; Dincecco and Katz 2014). Studies also show that a proactive state could accelerate the transition from stagnation to growth by implementing policies that promote human capital formation (Doepke 2004; Doepke and Zilibotti 2005; Galor and Moav 2006; Galor et al. 2009). ${ }^{11}$ In light of these works, our finding of an increasingly weak state in China in contrast to Japan might help explain the puzzle of China's late industrialization.

This paper builds directly upon Sng (2014), who studies the impact of geographical size on the principal-agent problem in late imperial China. Our work significantly extends his model by incorporating public goods provision and offers new comparative empirical evidence by bringing Japan into the picture. Our approach is complementary to Brandt et al. (2014), who provide a comprehensive survey of the long-run evolution of the Chinese political economy since the tenth century.

Importantly, four recent contributions also explore the impact of geographical proximity and size on the quality of political and corporate governance. Stasavage (2011) finds that in preindustrial Europe, high communication and travel costs prevented representative assemblies in large polities from convening regularly and functioning effectively. Using contemporary data from 127 countries, Olsson and Hansson (2011) detect strong negative effects of territorial size on the rule of law. Giroud (2013) shows that a reduction of travel time (a proxy for monitoring costs) between company headquarters and plants has positive effects

\footnotetext{
9 Ko and Sng (2013) and Ko et al. (2014) model the tradeoff and argue that a large empire could be a constrained optimum for China due to its geography.

10 In a concurrent study, Sakane (2011a) offers a brief but insightful discussion comparing the systems of tax collection in nineteenth-century Japan and China (pp. 235-239). More recently, Aoki (2014) analyzes the coevolution of political and economic institutions in the two countries.

11 State capacity is important in this context not only to finance these policies but also to overcome the resistance from entrenched interest groups. For example, Galor et al. (2009) show that powerful landlords tend to oppose the expansion of public education, and therefore successful land reforms could accelerate economic modernization.
} 


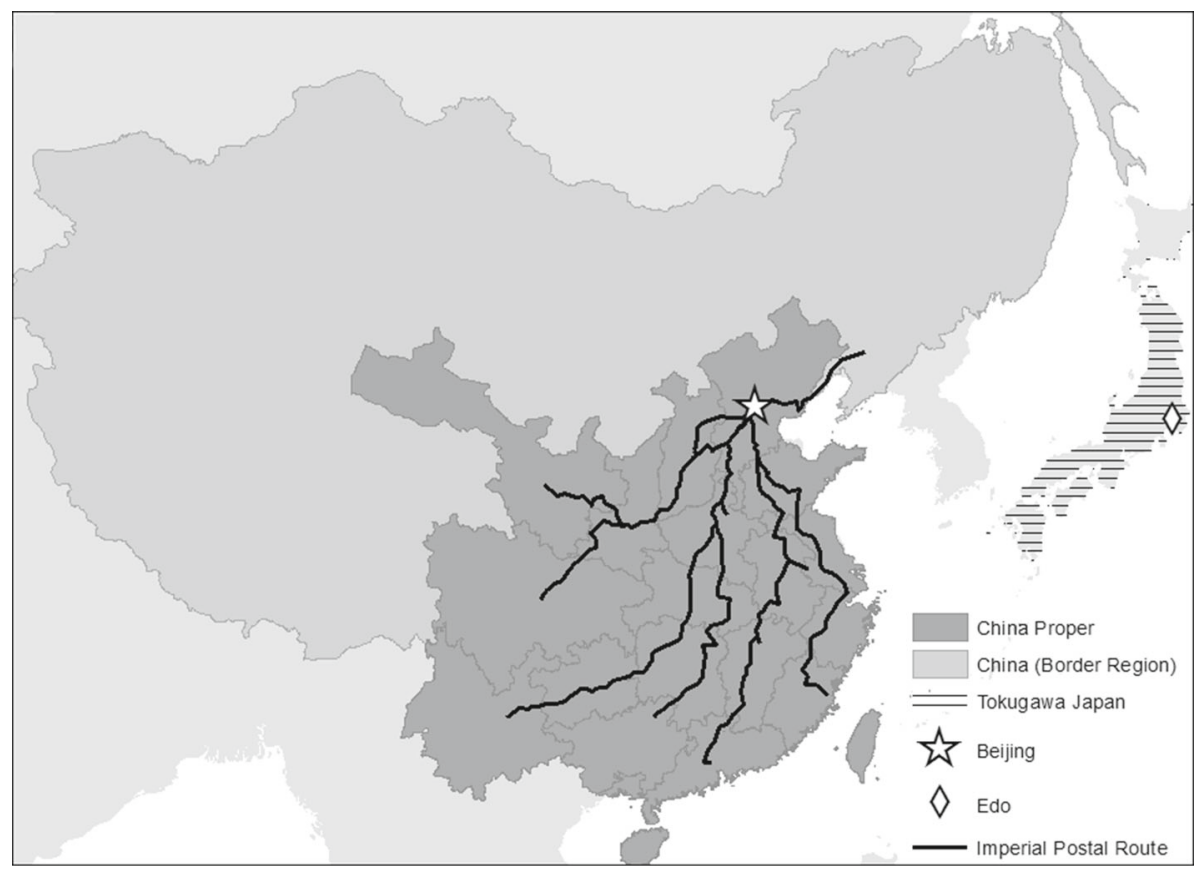

Fig. 2 Early modern China and Japan. Source: CHGIS, Version 4, Cambridge: Harvard Yenching Institute, January 2007

on plant-level productivity and profits. Campante and Do (2014) provide strong evidence that isolated capital cities in US states are associated with lower accountability, greater levels of corruption, and worse public goods provision. These studies show that distance and size are a challenge to good governance not only in premodern regimes in Asia and Europe, but also in modern states and corporations.

The rest of the paper is organized as follows: Section. 2 provides the historical background. Section 3 presents the model and derives predictions. Section 4 provides comparative historical evidence. Section 5 concludes.

\section{Historical background}

In this section, we compare the geography, administrative structure, and system of tax collection in Qing China and Tokugawa Japan to motivate our theoretical model.

\subsection{Geography}

Tokugawa Japan was an archipelago comprising three main islands, ${ }^{12}$ while China was a continental empire (Fig. 2). At its peak, China under the Qing dynasty (1644-1911) controlled a landmass larger than China or the United States today. Even if we disregard the thinly populated Inner Asian borderlands, the region known as China proper-the 18 provinces

12 During the Tokugawa period, Hokkaido was populated by the indigenous Ainu people and Japan's control was restricted to the southern tip of the island. 


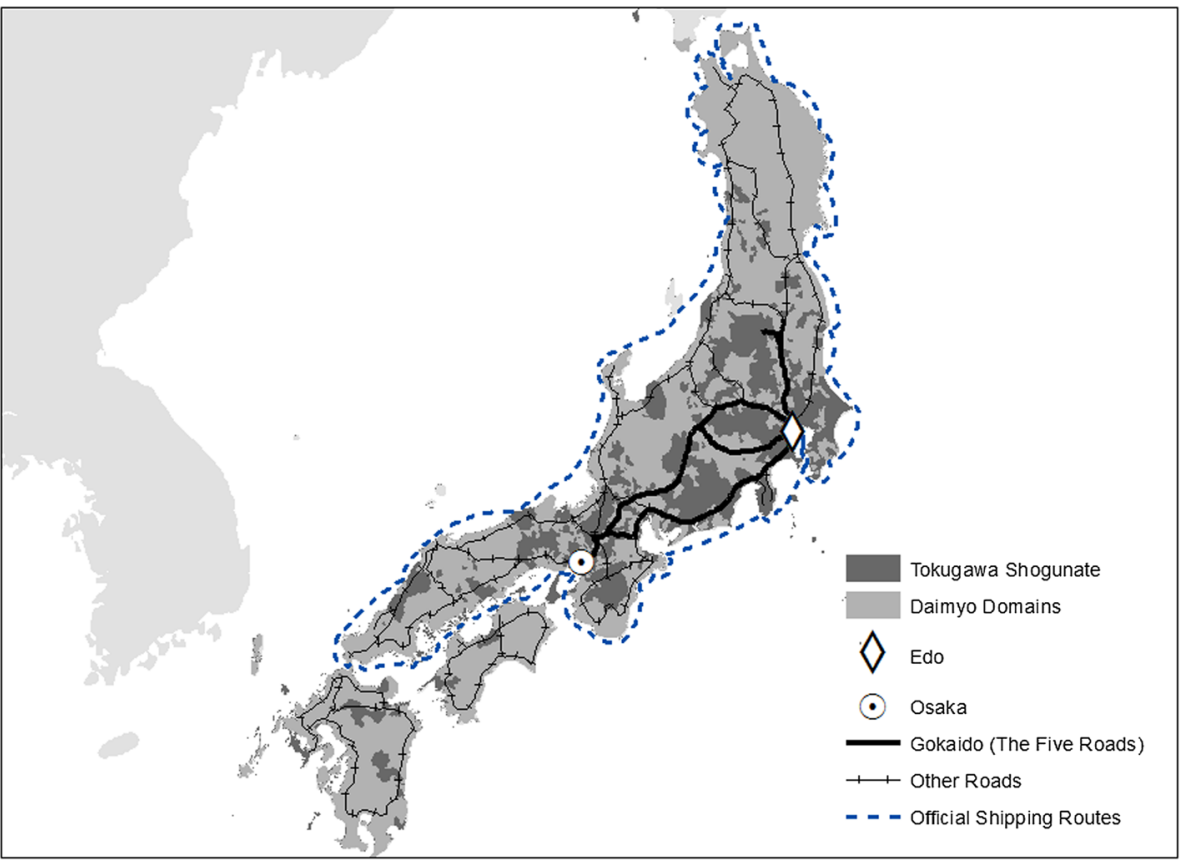

Fig. 3 Tokugawa Japan in 1664. Source: China Historical GIS Project, “Tokugawa Japan GIS, Demo Version." Feb 2004

between the Great Wall and the South China Sea, which accounted for about $98 \%$ of the empire's population-was still 12 times the size of Tokugawa Japan.

If information transmission posed any challenge to effective public administration, this challenge was clearly more acute in China than in Japan. To send a high-priority official document from Beijing 1000 kilometers down south to Shanghai would take up to 10 days (Xie 2002). By contrast, a similar trip between Japan's two biggest cities, Edo (Tokyo) and Osaka, about $520 \mathrm{~km}$ apart, would only require 4 days (Nakane and Oishi 1990). It is also worth noting that no one in Japan lived more than 120 kilometers from the sea, which offered a cheap mode of transportation in an age before railroads.

\subsection{Administrative structure}

Both China and Japan were ruled by a succession of stable dictators between 1650 and 1850 . However, while China was ruled by one dictator — the emperor of the Qing dynasty — during this period, multiple dictatorships coexisted in Japan.

Nominally, Japan was led by the shogun of the Tokugawa house, who controlled $15 \%$ of the arable land (Fig. 3). The bulk of the remaining land was divided into 260-odd mutually exclusive domains, each headed by a daimyo (local lord). ${ }^{13}$ While a daimyo had to swear allegiance to the shogun and subject himself to a system of controls aimed to prevent dissent,

13 The size of domains varied widely. The shogunate was rated at 4 million koku, but most domains were much smaller. The average size of a domain was only about 100,000 koku. 
he retained virtually complete autonomy over his domain. ${ }^{14}$ As such, instead of treating Tokugawa Japan as a unified but decentralized empire, we interpret it as a league of dictatorships and treat each daimyo as a dictator. ${ }^{15}$ We focus primarily on the shogunate, for which historical records are most abundant, and compare it with China proper. ${ }^{16}$

The systems of territorial administration in China proper and the shogunate were broadly similar. To administer his domain, the Qing emperor structured his bureaucracy into four layers (center-province-prefecture-local). China proper was organized into 18 provinces; each province was then divided into several prefectures, and each prefecture into several counties. The responsibility of local administration fell on the county, which sat at the bottom of the bureaucratic hierarchy. Each county was headed by a magistrate, whose term was usually limited to 3 years (Ch'u 1962).

In the Tokugawa shogunate, local administration was also carried out by nonhereditary magistrates (daikan). Like his Chinese counterpart, the shogunate magistrate was subjected to rotation. ${ }^{17}$ They also shared a similar scope of responsibilities. In both regimes, the magistrate was expected to focus on two tasks: collection of taxes and adjudication of disputes (Wang 1985; Totman 1967).

There were only two layers of government (center-local) in the shogunate. At any one time, 40-50 magistrates reported directly to the shogun's cabinet (Totman 1967). By contrast, there were about 1,500 county-level jurisdictions and hence 1,500 magistrates in Qing China. A shogunate magistrate typically governed 50,000-100,000 people, while the size of an average Chinese county ranged from 100,000 (in 1700) to 300,000 (in 1850).

\subsection{Monitoring system}

Because China proper was almost 90 times bigger than the shogunate domain, it had a greater number of administrative officials and a longer bureaucratic chain of command. This implies that unless the Chinese emperor possessed superior monitoring technologies, it would be more difficult for him than for the shogun to monitor local officials. There is little evidence to suggest that monitoring technologies were better in China, however. In fact, the two regimes instituted similar monitoring systems that combined top-down, parallel, and bottom-up monitoring.

In top-down monitoring, local officials were supervised by higher-ranking officials within the same bureaucratic hierarchy. In the shogunate, the magistrate's office was periodically audited by the Finance Office in Edo (Totman 1967, p. 76). In China, the administration

\footnotetext{
14 The position of the shogun in relation to other daimyo could be seen as one of "first among equals." He could order a daimyo to provide military and logistical support or to make contributions to public projects (e.g., castles, roads, and bridges). However, he had no right to tax daimyo lands. An important mechanism imposed by the shogun to ensure daimyo subservience was sankin kotai. Essentially a hostage system, it required a daimyo to maintain two residences-one in the daimyo domain and the other in Edo-and to spend alternate years at each place. When the daimyo was absent from Edo, his wife and heir were required to stay there as hostages. This and other measures helped maintain an extended period of peace known as Pax Tokugawa.

15 An analogy can be found in the theory of the firm, which equates ownership to a firm with the control of residual rights to its assets (Grossman and Hart 1986). Since a daimyo was the residual claimant to the fiscal resources of his domain, he, not the shogun, owned the domain.

16 Due to the shogunate's strong political and economic influences, the institutional features of local domains shared much in common with those of the shogunate domain (Nakabayashi 2012). However, due to data limitations, we leave a detailed analysis of other domains to future work.

${ }^{17}$ In the early years of the shogunate, the magistrate office was hereditary and was often held by powerful local families. In 1680, the shogun Tsunayoshi initiated administrative reforms and replaced the hereditary system with a more meritocratic system. After the reforms, a typical magistrate would serve in 2.54 locations in his lifetime and spend 5.7 years in each location (Nishizawa 1998).
} 
conducted a grand review once every three years to evaluate the magistrate's performance and mete out reward or punishment accordingly (Watt 1977).

Top-down monitoring, however, could be ineffective in the presence of bureaucratic patronage networks. To prevent this, the Chinese emperor established an independent surveillance agency known as the Censorate to detect bureaucratic malpractices and report them to the emperor (Feuerwerker 1976). Likewise, the shogun sent out censors to keep an eye on the local administration (Totman 1967; Nakane and Oishi 1990).

Finally, to carry out bottom-up monitoring, both regimes adopted petition systems. The system had a long tradition in China, where it had been in place since the seventh century (Ocko 1988; Fang 2009). In Japan, it was not until 1720 that the shogun set up petition boxes in major cities and permitted the public to make suggestions for better governance or to report misconduct and abuse of power by shogunate officials. The petitions were sent directly to the shogun for his review. Over $75 \%$ of large local domains instituted similar systems (Ohira 2003).

In both cases, the petition system was costly to implement, as it typically generated a large number of petitions including irrelevant requests and false accusations. In the Tokugawa shogunate, each petition was investigated and petitioners were punished for misstatements. The system functioned reasonably well and was maintained until the end of the Tokugawa period (Ohira 2003). ${ }^{18}$

By contrast, the sheer size of the Chinese population made it extremely costly for the Qing rulers to verify the authenticity of every petition. Both the emperors Qianlong (r. 1736-1795) and Jiaqing (r. 1796-1820) initially encouraged petitions from their subjects but quickly reversed their policies after receiving a flood of complaints that they could not possibly deal with (Fang 2009). The system did not function as intended, and some complainants resorted to extreme measures, such as committing suicide outside the palace gates, to attract the emperor's attention to their grievances. In other words, although both China and Japan used similar systems of bottom-up monitoring to check corruption, it was less effective in China due to its much greater size and population.

The rulers in China and Japan were concerned about the well-being and grievances of their subjects for both ideological and practical reasons. Because Confucianism demanded rulers to treat their subjects benevolently, it legitimized popular resistance against an oppressive ruler. ${ }^{19}$ This fear of a violent rebellion served as a constraint on dictators in both China and Japan and gave them an incentive to prevent the overexploitation of their subjects.

\subsection{The system of tax collection}

Land taxation was the most important source of government revenue in both Qing China and Tokugawa Japan. Both economies depended heavily on small-scale, labor-intensive agriculture. Every land-holding household was obligated to pay the land tax, the amount of which was determined based on the size and quality of the land the family held (Ch'u 1962; Nakane and Oishi 1990). In the case of Japan, the fiscal base was measured in rice, the primary staple crop nationwide. Fields, forests, residential lands, mines, and fishing grounds were also assessed and taxed in terms of rice (Nishikawa 1985, pp. 23-24). If rice were not the

\footnotetext{
18 In addition to exposing corruption, petitions also contributed to the creation of fire brigades and the establishment of a hospital for the poor in Edo (Roberts 1994).

19 In the words of Mencius, "If a prince treats his subjects as his hands and feet, they will treat him as their belly and heart. If he treats them as his horses and hounds, they will treat him as a mere fellow-countryman. If he treats them as mud and weeds, they will treat him as an enemy" (Mencius 2004).
} 
main crop cultivated, then part of the tax would be levied in cash at a conversion rate set by the lord.

By contrast, regional diversity necessitated the denomination and collection of taxes in a variety of crops and metals in China. Although most taxes had been monetized by the seventeen century, the peasants still had to pay part of their land taxes in kind, which, depending on the region, could be rice, wheat, millet, barley, sorghum, beans, or other staple crops. Furthermore, it was common for the portion of the land tax denominated in silver to be paid in copper coins when and where silver was scarce (Ch'u 1962). In such cases, commutation rates were set by magistrates based on local conditions. This high heterogeneity created great difficulties for the imperial court to monitor the over-collection of taxes by the county administration (Ch'u 1962; Zelin 1984).

In Qing China, the primary unit of taxation was the household, whereas in Tokugawa Japan, it was the village instead of the household. Under the village contract system (murauke), the Japanese rulers levied the land tax on each village based on its total assessed yield. Village leaders were in charge of assigning and collecting taxes from individual households and transferring the sum to the magistrate. Moreover, households in the same village were made collectively responsible for the payment of taxes. This arrangement reduced the frequency of contact between the magistrate and individual peasants and, therefore, limited the opportunities for tax officials to abuse power. Indeed, the magistrate rarely showed up in the villages except for annual inspections, and villages retained a high degree of autonomy in running their affairs in Japan (Walthall 1991).

For this system to work, it was necessary that village communities remained tightly knit to facilitate mutual monitoring and discourage free riding. To restrict geographical mobility, the shogunate and local lords mandated every village to keep a household registry and required their subjects to obtain permission before changing residency or traveling.

We do not model the village contract system in Japan in the next section as doing so would further reduce the monitoring costs for the Japanese rulers and strengthen our main results. It should be noted, however, that the village contract system was not a uniquely Japanese system. In fact, China had instituted a similar system during the Ming dynasty (1368-1644). The system eventually unraveled, however, as the potential for migration given China's vast inner frontiers made it difficult to maintain tightly knit communities that were necessary to implement collective responsibility. ${ }^{20}$ By contrast, the village contract system was firmly institutionalized in Tokugawa Japan. Even though it was abolished by the Meiji government with the introduction of a new land tax system, tax collection was delegated to local communities that continued to use a collective responsibility system well into the 1930s (Sakane 2011b).

We also do not incorporate taxpayer heterogeneity in our model. In China, taxpayers could be broadly classified into two groups: the gentry and the peasants. Historical studies suggest that unlike ordinary peasants, the gentry were rarely subjected to bureaucratic extortion because of their political connections (Ch'u 1962; Watt 1977). ${ }^{21}$ Some gentry took advantage

20 As in Tokugawa Japan, the primary unit of land taxation in Ming China was the self-governing village (Huang 1974). The Ming state also heavily restricted domestic and foreign traveling. However, large-scale population movements to the inner frontiers in the sixteenth century put this system under increasing pressure. The migration of a household implies that the remaining households had to shoulder extra corvée responsibilities. This in turn increased the incentives for others to migrate, setting off a chain reaction that caused the system to unravel (Heijdra 1998; Fei 2007). By the seventeenth century, the unit of taxation was switched from the village to the household.

21 The gentry was an elite minority, constituting $1.3 \%$ of the Chinese population around 1,800 (Zhang 1955). As holders of official educational degrees, they belonged to the same social class as the magistrate and some had ties with high-level government officials. 
of their sheltered position to act as tax farmers, earning extralegal income by paying taxes on the peasants' behalf and charging for the service.

There was heterogeneity among taxpayers in Japan too, although not to the extent observed in China. Under the village contract system, wealthy peasants were typically appointed as village leaders. Some village leaders took advantage of their position and colluded with the magistrate to extort the villagers (Nishizawa 2004).

Based on these observations, we consider local elites (the gentry and the village leaders) as tax intermediaries instead of taxpayers and incorporate them as a constituent of the tax agent. $^{22}$

\section{The model}

Motivated by the historical observations, in this section we develop a formal model to study the impact of geographical size on a ruler's capacity to collect taxes and provide public goods.

Consider a discrete-time, infinite-horizon game with three types of players: ruler, tax agents, and peasants. As a stable dictator with dynastic succession, the ruler is assumed to live infinitely long, while the agents and the peasants are assumed to be short-lived.

For analytical simplicity, we assume that the dictatorship consists of $S$ homogenous regions and that $S$ is exogenously given to the Ruler. ${ }^{23}$ We let the number of regions $S$ represent the geographical size of the dictatorship and take a region as the unit of analysis. In other words, when comparing large and small dictatorships, we assume that the two regimes differ only in the number of regions they encompass and that all regions in the two regimes are "identical."

\subsection{The basic setup}

We first describe a basic, single-period game in a representative region consisting of a fixed number of jurisdictions. ${ }^{24}$ Assume that the region is populated by $N$ Peasants who engage in agricultural production. ${ }^{25}$ Let $Y$ denote the agricultural output in the region and assume that it increases with labor inputs at a diminishing rate: $Y=Y(N)$, where $N>0, Y(0)=0$, $Y^{\prime}(\cdot)>0$, and $Y^{\prime \prime}(\cdot)<0$. In other words, the aggregate output increases with population, and hence population growth and economic growth are synonyms in our model.

In each region, the ruler sets a tax rate $\tau$ and stations a fixed number of Agents to collect taxes from the Peasants, where one Agent is assigned to every jurisdiction. ${ }^{26}$ We interpret the Agent as a figure that represents all tax intermediaries in his jurisdiction. ${ }^{27}$ When collecting

22 Our main results will not change if we incorporate taxpayer heterogeneity and model the local elites as taxpayers with political connections.

23 In historical terms, in the case of Qing China, a region corresponds to a province and thus $S=18$; in the case of Tokugawa Japan, the entire Shogunate domain can be seen as just one region, and thus $S=1$.

24 In historical terms, one region consisted of approximately 83 jurisdictions in Qing China and approximately 50 jurisdictions in the Tokugawa shogunate.

25 For simplicity, we assume away commercial production, but it can be incorporated without changing the main results.

26 In historical terms, the official tax rate $\tau$ includes not only the tax rate explicitly stipulated by the ruler, but also the rate of informally approved surcharges to cover local expenses (see footnote 36 for details).

27 In historical terms, in China the Agent represents the magistrate, the county subofficials, and the gentry; in Japan the Agent represents the magistrate, his subordinates, and the village leaders. We implicitly assume that the local elites were equally influential in China and Japan. Since the gentry in China likely controlled more political and economic resources than the village leaders in Japan did, modeling this difference will only strengthen our results. 
taxes, the agent may demand extralegal surcharge of rate $\theta$ from the peasants, in addition to the official tax rate $\tau$, for his private benefit. As a result, the effective expropriation rate for the peasants is $\tau+\theta$, creating a potential wedge between what the ruler receives and what the peasants pay.

When the agent announces $\tau+\theta$, the Peasants pay the portion of their outputs to the agent as demanded. ${ }^{28}$ If $\tau+\theta$ is within an exogenously given rate of $r$, then the Peasants consider it acceptable and stay put. However, if it exceeds $r$, then the peasants deem this "unjust" and revolt. We assume that only the ruler actively seeks to prevent rebellion for three reasons. First, because peasant rebellion destroys productive capacity and affects future agricultural outputs, it hurts the long-lived ruler much more than the short-lived agents. Second, within each jurisdiction there are coordination problems among tax intermediaries that collectively constitute the agent. Even if revolts hurt them, it is individually rational for each of them to ignore the no-revolt condition in setting $\theta$. Third, a rebellion could spill over to other jurisdictions. If agents in different jurisdictions cannot coordinate their actions in setting $\theta$, then it will be individually rational to ignore the no-revolt condition. By contrast, as the sole dictator governing the entire domain, the ruler internalizes externalities across both time and space.

To discourage the agents from engaging in extralegal expropriation, the ruler employs the following monitoring mechanism. First, the ruler conducts audits in randomly selected regions after the agents finish tax collection. Let $A(S)$ denote the probability of the representative region receiving audits where $0 \leq A(S) \leq 1$. Due to the ruler's resource constraints, we assume that the probability of audits decreases with the number of regions in a dictatorship: $A^{\prime}(\cdot)<0 .{ }^{29}$ In other words, in the absence of modern information technologies, the ruler faces managerial diseconomies of scale.

Next, when an agent is indicted on misconduct charges in the auditing process, the ruler punishes the agent by imposing a fine $X$. Audits, however, detect misconduct only imperfectly with probability $D(\theta)$ where $0 \leq D(\theta) \leq 1$ and $D(0)=0$. We assume that the detection probability increases with the rate of surcharge $\theta$ at an increasing rate, but that the marginal rate of detection is concave in $\theta: D^{\prime}(\cdot)>0, D^{\prime \prime}(\cdot)>0$, and $D^{\prime \prime \prime}(\cdot) \leq 0 .{ }^{30}$ A simple example would be a quadratic function: $D(\theta)=\theta^{2}$.

To summarize, the timing of events in the basic, single-period game in the representative region is as follows: (1) The ruler sets a tax rate $\tau$ to maximize tax revenue. (2) The representative Agent selects $\theta$ to maximize his expected payoff and proceeds to collect taxes. (3) The

\footnotetext{
28 We assume that the tax unit is an individual. Incorporating the village contract system in Tokugawa Japan in the model would further reduce the monitoring costs for Japanese rulers and strengthen our results.

29 For simplicity, we use $A(\cdot)$ as the reduced form representation of the ruler's auditing strategy. To endogenize $A$, suppose the ruler is free to select the fraction of $S$ regions to audit, but audits are costly as they consume his time and attention. If the cost of audits is increasing in $A \cdot S$ (the total amount of audits conducted) at an increasing rate, and if we assume an interior solution, then $A^{\prime}(\cdot)<0$ follows.

30 For simplicity, we use $D(\cdot)$ and $X$ as the reduced form representation of the ruler's monitoring strategy and directly impose assumptions. The above assumptions, however, can be justified as follows. Suppose that when the agent collects a surcharge of $\theta$, then an audit will reveal a signal $\hat{\theta}$ drawn from a normal distribution $N\left(\theta, \sigma^{2}\right)$ bounded between 0 and 1 (i.e., truncated normal distribution). Suppose that the ruler punishes the Agent whenever $\hat{\theta}$ is greater than some threshold value $h$. This delivers the properties $D(0)>0$ and $D^{\prime}(\cdot)>0$. Ignoring corner solutions, it can be further verified that the Agent will never set $\theta$ beyond the threshold $h$, which in turn implies that we can focus on the values of $\theta$ that correspond to $D^{\prime \prime}(\cdot)>0$. Moreover, it can be shown that if $\sigma$ is large enough (i.e., if the ruler's information is sufficiently noisy), then $D^{\prime \prime \prime}(\cdot) \leq 0$. Finally, even though the ruler can choose a level of fine from a range of possible values, in equilibrium the ruler will always choose the maximum fine, which gives $X$ in our model.
} 
peasants pay $\tau+\theta$ of their outputs to the agents and decide whether or not to revolt. (4) The ruler conducts randomized audits and punishes the agents if the audits uncover misconduct.

The representative agent To provide benchmark results, we derive the equilibrium of the single-period game. First, consider the optimization problem of the representative agent. The Agent chooses a rate of extralegal surcharge $\theta$ to maximize his expected payoff, given the monitoring mechanism, $A(\cdot), D(\cdot)$, and $X$ :

$$
\max _{0 \leq \theta \leq 1} v^{A}=\theta \cdot Y(N)-A(S) \cdot D(\theta) \cdot X
$$

The optimal rate of surcharge $\theta^{*}$ is given by the following condition:

$$
Y(N)=A(S) \cdot D^{\prime}\left(\theta^{*}\right) \cdot X
$$

The ruler The ruler chooses a tax rate to maximize tax revenue. In doing so, however, we assume that, unlike the agents, the ruler is deeply concerned about peasant rebellion and thus constrained by the no-revolt condition: $\tau+\theta \leq r$.

Formally, the ruler's maximization problem can be written as:

$$
\begin{array}{ll} 
& \max v^{R} v^{R}=\tau \cdot Y(N) \\
\text { s.t. } & \tau+\theta \leq r
\end{array}
$$

Anticipating the responses by the agents and the peasants, the ruler sets a tax rate given the optimality condition (2) and the no-revolt condition. It is simple to show that there is a unique equilibrium in the single-period game in which $\tau^{*}$ and $\theta^{*}$ are determined by $Y(N)=A(S) \cdot D^{\prime}\left(\theta^{*}\right) \cdot X$ and $\tau^{*}+\theta^{*}=r$.

Comparative statics To examine the effects of the size of a dictatorship on the optimal tax and corruption rates, we perform comparative statics with respect to the number of regions $S$. From the optimality condition $Y(N)=A(S) \cdot D^{\prime}\left(\theta^{*}\right) \cdot X$ and the assumptions $A^{\prime}(S)<0$ and $D^{\prime \prime}(\theta)>0$, we obtain the following result:

Result 1 The equilibrium corruption rate $\theta^{*}$ is higher in a larger dictatorship: $\frac{d \theta^{*}}{d S}>0$.

From $\tau^{*}+\theta^{*}=r$, it also follows that:

Result 2 The equilibrium tax rate $\tau^{*}$ is lower in a larger dictatorship: $\frac{d \tau^{*}}{d S}<0$.

In other words, assuming that production and monitoring technologies are identical across comparable regions in the two dictatorships, the model predicts lower official tax rates and higher extralegal expropriation rates in Qing China than in Tokugawa Japan. These results are driven solely by the assumption of managerial diseconomies of scale, $A^{\prime}(S)<0$.

\subsection{The dynamic setup}

We now consider a dynamic game $(t=1,2,3 \ldots)$ and introduce two additional features. First, to provide a link between tax revenue and the economy, we allow the ruler to spend part of the revenue on a local public good. Second, to study dynamic implications, we endogenize population and permit the economy to grow.

If the ruler spends all tax revenue on nonproductive pursuits, such as private consumption, then from an economic point of view, there is little difference between taxation and corruption. Suppose, however, that the ruler spends part of the tax revenue on public goods in each region. For simplicity, assume that a random shock (e.g., natural disaster) hits the representative region at the end of every period. Assume also that the ruler can invest in a public good in 
the beginning of every period to prepare for the possible disaster. We consider a local public good (as opposed to a pure public good) that is non-excludable but rivalrous within the region and has no spillover effects on other regions. Most infrastructure investments, such as roads, flood control, fire protection, and famine relief, satisfy these conditions and must be provided on a regional basis.

Let $\gamma_{t}$ be the level of public good the ruler provides in period $t$. Unless the level of public good investment is sufficiently large relative to the size of the shock, the shock destroys the region's economy and terminates the game at the end of period $t$. Let $G\left(\gamma_{t}\right)$ denote the probability that the region survives the shock and the game continues into period $t+1$ given the investment $\gamma_{t}$. We assume that the continuation probability increases with $\gamma_{t}$ but at a diminishing rate: $G(0)=0, G^{\prime}(\cdot)>0$, and $G^{\prime \prime}(\cdot)<0 .{ }^{31}$ In other words, the ruler now has an incentive to invest in the public good to protect the regional economy from the random shock to secure future tax revenue. ${ }^{32}$

Next, we model consumption and reproduction decisions of a representative peasant. Assume that the peasant lives for just one period, earns income from agricultural production, and spends his after-tax income on consumption and reproduction to maximize his utility. ${ }^{33}$ Let $u\left(c_{t}, n_{t+1}\right)$ represent the utility the peasant receives from the consumption $c_{t}$ and the number of offspring $n_{t+1}$ produced in period $t$. Collectively, $n_{t+1}$ gives total population in the next period $N_{t+1}$, namely, $N_{t+1}=N_{t} \cdot n_{t+1}$. Following Hansen and Prescott (2002), we assume that the two goods are complements and are subject to diminishing marginal utility: $u_{1}()>0,. u_{2}()>0,. u_{11}()<0,. u_{22}()<0,. u_{12}()>$.0 .

The timing of events in the dynamic game in period $t(t=1,2,3 \ldots)$ is as follows: (1) The ruler sets a tax rate $\tau_{t}$ and public good investment $\gamma_{t}$. (2) The representative agent selects a rate of extralegal expropriation $\theta_{t}$. (3) The representative peasant pays $\tau_{t}+\theta_{t}$ of his income to the Agent, makes consumption and reproductive decisions $\left(c_{t}, n_{t+1}\right)$, and revolts if $\tau_{t}+\theta_{t}>r$. (4) The ruler conducts randomized audits and fines the agents if misconduct is detected. (5) Exogenous shock hits the region and destroys the economy unless $\gamma_{t}$ is sufficiently large; the game continues to the next period with probability $G\left(\gamma_{t}\right)$.

The representative peasant We derive an equilibrium of the dynamic game by backward induction.

First, the optimization problem of the representative Peasant in period $t$ is given by:

$$
\begin{aligned}
\max _{c_{t}, n_{t+1}>0} u_{t} & =u\left(c_{t}, n_{t+1}\right) \\
\text { s.t. } & c_{t}+n_{t+1} \leq\left[1-\tau_{t}-\theta_{t}\right] \cdot y_{t}
\end{aligned}
$$

where individual income is defined by $y_{t}=\frac{Y\left(N_{t}\right)}{N_{t}}$. Note that $y_{t}$ is exogenous to the peasant even though $N_{t}=N_{t-1} \cdot n_{t}$ because $n_{t}$ is a decision variable of the previous generation.

\footnotetext{
${ }^{31}$ For example, let $W_{t}$ denote the realization of the shock in period $t$, and assume that the shock destroys the economy if $\gamma_{t}<W_{t}$. Suppose that $W_{t}$ is the absolute value of a normally distributed random variable with mean 0 and variance $\sigma^{2}$. Then, it follows that $G\left(\gamma_{t}\right)=F\left(\gamma_{t} ; 0, \sigma^{2}\right)-F\left(-\gamma_{t} ; 0, \sigma^{2}\right)$ and thus $G(0)=0$, $G^{\prime}(\cdot)>0$, and $G^{\prime \prime}(\cdot)<0$.

32 More generally, the ruler may invest in public goods that directly increase the agricultural output $Y$ in the region. In our model, we consider public goods that only affect the continuation probability as it immeasurably simplifies the analysis.

33 In our model, when making reproduction decisions, individual peasants do not take into consideration the negative externalities of producing offspring today on the living standard of the next generation. We assume that even if each peasant cares about the well-being of his offspring in the next period, peasants in the region are unable to act collectively to regulate population growth to attain a socially optimal level of income. As such, individual peasants take $N_{t+1}$ and thus $y_{t+1}$ as exogenous and beyond their control.
} 
From the first order condition and the assumption $u_{12}()>$.0 , it can be shown that the optimal number of offspring $n_{t+1}^{*}$ is an increasing function of net individual income $\left(1-\tau_{t}-\theta_{t}\right) \cdot y_{t}$.

The representative agent The representative Agent is assumed to be short-lived. As a result, the maximization problem of the representative Agent is essentially the same as in the single-period game, and thus the optimal rate of extralegal expropriation in period $t$ is given by:

$$
Y\left(N_{t}\right)=A(S) \cdot D^{\prime}\left(\theta_{t}^{*}\right) \cdot X
$$

The ruler The ruler is assumed to live for infinitely many periods. He sets the current and future values of $(\tau, \gamma)$ to maximize the expected discounted value of the tax revenue stream. In doing so, we again assume that the ruler is bound by the no-revolt condition in every period. Let $V_{t}^{R}$ represent the ruler's present value of the future revenue stream in period $t$. His maximization problem in period $t$ is given by:

$$
\begin{aligned}
\max _{0 \leq \tau_{t+j} \leq 1, \gamma_{t+j} \geq 0} V_{t}^{R}=\tau_{t} \cdot Y\left(N_{t}\right)-\gamma_{t}+G\left(\gamma_{t}\right) \cdot V_{t+1}^{R} \\
\text { s.t. } \tau_{t+j}+\theta_{t+j} \leq r \quad \forall j=0,1,2 \ldots
\end{aligned}
$$

The optimal level of public good investment $\gamma_{t}$ is given by the following condition:

$$
G^{\prime}\left(\gamma_{t}^{*}\right) \cdot V_{t+1}^{R *}=1
$$

In other words, the ruler invests in the public good up to the level where the marginal return from the investment equals its marginal cost. The higher the present value of his future revenue stream $V_{t+1}^{R *}$, the more willing the ruler is to invest in the public good to increase the continuation probability.

The ruler sets an optimal tax rate, taking the agent's optimality condition (6) and the Peasant's no-revolt condition as given. Because these conditions are the same as before, the equilibrium tax and corruption rates $\left(\tau_{t}^{*}, \theta_{t}^{*}\right)$ in the dynamic game are again determined by $Y(N)=A(S) \cdot D^{\prime}\left(\theta_{t}^{*}\right) \cdot X$ and $\tau_{t}^{*}+\theta_{t}^{*}=r(t=1,2,3 \ldots)$.

Population dynamics We now turn to equilibrium population dynamics. Because the Peasant's net income is $(1-r) \cdot y_{t}$ in the equilibrium and $r$ is a constant, the optimal number of offspring can be expressed as $n_{t+1}^{*}=n_{t+1}^{*}\left(y_{t}\right)$, where $n_{t+1}^{*}(\cdot)$ is strictly increasing in $y_{t}$. This, in turn, provides the population dynamics because by definition:

$$
n_{t+1}^{*}\left(y_{t}\right)=\frac{N_{t}^{*} \cdot n_{t+1}^{*}}{N_{t}^{*}}=\frac{N_{t+1}^{*}}{N_{t}^{*}}
$$

In the spirit of Malthus, Condition (9) implies that the direction and rate of population growth depends on the peasant's per capita income. Let $\underline{y}$ denote the level of income defined by $n_{t+1}^{*}(\underline{y})=\frac{N_{t+1}^{*}}{N_{t}^{*}}=1$. If $y_{t}>\underline{y}$, then $N_{t+1}>N_{t}$ or population will expand; if $y_{t}<\underline{y}$ instead, then population will contract. Either way, in the long run the region's population will converge to a stationary level $N(\underline{y})$ associated with the steady-state per capita income $\underline{y}$ (see Fig. 4).

\subsubsection{Comparative statics}

We compare the two dictatorships that differ only in the number of regions that they encompass. In particular, we assume the same initial populations in the representative regions in the two dictatorships. Recall that the optimal tax rate is higher in a smaller dictatorship in every period (Result 2). However, since population growth depends not on the official tax rate $(\tau)$ 


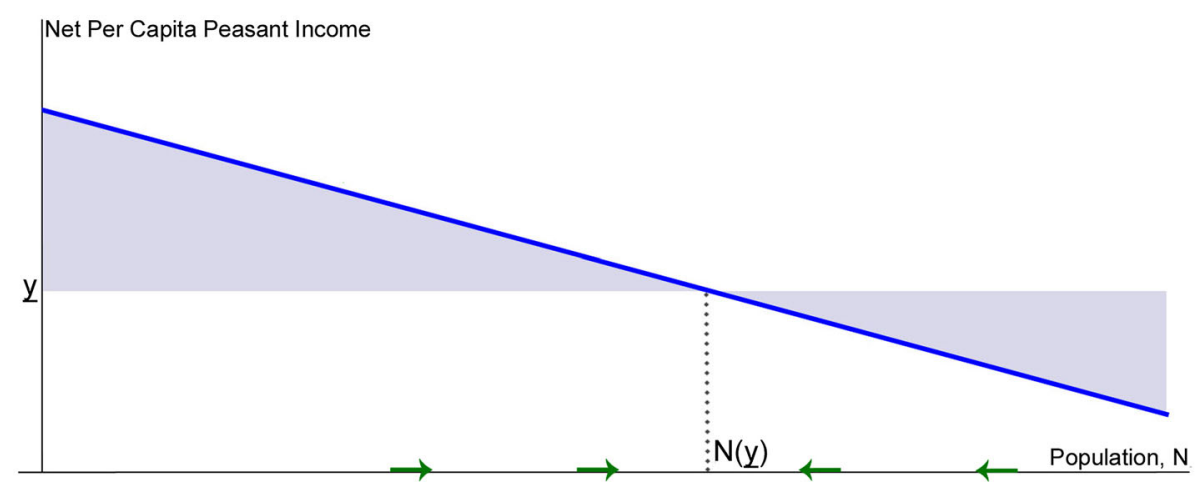

Fig. 4 Converging to the steady state population level

alone, but on the effective expropriation rate $(\tau+\theta)$, the two representative regions will be identical in population size in every period.

Result 3 A larger dictatorship invests less in the public good per region (and therefore per capita): $\frac{d \gamma_{t}^{*}}{d S}<0 \forall t$.

Proof Suppose that the result does not hold; at some $t, \gamma_{t}^{*}\left(S_{\text {large }}\right) \geq \gamma_{t}^{*}\left(S_{\text {small }}\right)$, where $S_{\text {large }}>S_{\text {small }}$. Let $\left\{\gamma_{t+j}^{*}\left(S_{\text {large }}\right)\right\}_{1}^{\infty}$ represent the sequence of public good provision that maximizes $V_{t+1}^{R}\left(S_{\text {large }}\right)$ at $t$. Given Result 2, this sequence is financially feasible for the ruler of the smaller dictatorship to adopt. Let $U$ represent the value of $V_{t+1}^{R}\left(S_{\text {small }}\right)$ when he implements this sequence. Let $V_{t+1}^{R *}\left(S_{\text {small }}\right)$ represent the maximum attainable value of $V_{t+1}^{R}\left(S_{\text {small }}\right)$. By definition, $V_{t+1}^{R *}\left(S_{\text {small }}\right) \geq U$.

Result 2 implies that $U>V_{t+1}^{R *}\left(S_{\text {large }}\right)$. Therefore, $V_{t+1}^{R *}\left(S_{\text {small }}\right)>V_{t+1}^{R *}\left(S_{\text {large }}\right)$ must hold. The ruler's optimality condition (8) and the assumption $G^{\prime \prime}(\cdot)<0$ then imply that $\gamma_{t}^{*}\left(S_{\text {large }}\right)<\gamma_{t}^{*}\left(S_{\text {small }}\right)$. This completes the proof by contradiction.

The intuition of Result 3 is straightforward. When the agency problem is more severe and hence the continuation payoff $V_{t+1}^{R *}$ is lower, then the ruler has less incentive to invest in the future of the region. For ease of exposition, we assume that the agency problem exists only in tax collection but not in public goods provision. Historically, however, the agency problem in the provision of public goods was a serious concern as shown in the next section. Relaxing this assumption will only strengthen the result.

Next, we explore dynamic implications. We focus on the case where the initial size of the region's population is below the stationary level $N(y)$. According to the equilibrium population dynamics, the population will grow until it reaches the steady state unless interrupted by external shocks. Because aggregate output $Y(N)$ increases with the population, one may expect the ruler's tax revenue to increase with the population too. The next result, however, establishes that the ruler's revenue first rises and then falls as the population expands.

Result 4 For any given $S$, there exists a unique threshold population $\hat{N}(S)$ such that the ruler's period tax revenue $v_{t}^{R *}$ increases with $N$ if $N<\hat{N}(S)$, and decreases with $N$ if $N>\hat{N}(S)$. Moreover, the threshold population $\hat{N}(S)$ is smaller in a larger dictatorship: $\frac{d \hat{N}(S)}{d S}<0$. 
Proof From the agent's optimality condition $Y(N)=A(S) \cdot D^{\prime}\left(\theta^{*}\right) \cdot X$ and the assumptions $Y(\cdot)>0, Y^{\prime}(\cdot)>0, D^{\prime}(\cdot)>0$, and $D^{\prime \prime}(\cdot)>0$, it follows that:

$$
\frac{d \theta^{*}}{d N}=\frac{Y^{\prime}(N)}{A(S) \cdot X \cdot D^{\prime \prime}\left(\theta^{*}\right)}=\frac{D^{\prime}\left(\theta^{*}\right) \cdot Y^{\prime}(N)}{D^{\prime \prime}\left(\theta^{*}\right) \cdot Y(N)}>0
$$

which implies that the equilibrium corruption rate is strictly increasing in population.

Recall that the ruler's period tax revenue is given by $v^{R *}=\tau^{*} \cdot Y(N)$. Note that $\tau_{t}^{*}+\theta_{t}^{*}=r$ implies $\frac{d \tau^{*}}{d N}=-\frac{d \theta^{*}}{d N}$. Then it follows that:

$$
\begin{aligned}
\frac{d v^{R *}}{d N} & =\tau^{*} \cdot Y^{\prime}(N)+\frac{d \tau^{*}}{d N} \cdot Y(N) \\
& =\left[\tau^{*}-\frac{D^{\prime}\left(\theta^{*}\right)}{D^{\prime \prime}\left(\theta^{*}\right)}\right] \cdot Y^{\prime}(N)
\end{aligned}
$$

From $\frac{d \theta^{*}}{d N}>0, D^{\prime \prime}(\cdot)>0$ and $D^{\prime \prime \prime}(\cdot) \leq 0, \frac{D^{\prime}\left(\theta^{*}\right)}{D^{\prime \prime}\left(\theta^{*}\right)}$ is strictly increasing in $N .{ }^{34}$ Because $\frac{d \tau^{*}}{d N}<0, \tau^{*}-\frac{D^{\prime}\left(\theta^{*}\right)}{D^{\prime \prime}\left(\theta^{*}\right)}$ is a strictly decreasing function of $N$. Since $Y^{\prime}(\cdot)>0$, the sign of $\frac{d v^{R *}}{d N}$ is determined by the sign of $\tau^{*}-\frac{D^{\prime}\left(\theta^{*}\right)}{D^{\prime \prime}\left(\theta^{*}\right)}$. Let $\hat{N}(S)$ be the population level at which $\tau^{*}-\frac{D^{\prime}\left(\theta^{*}\right)}{D^{\prime \prime}\left(\theta^{*}\right)}=0$. It is simple to verify that $\frac{d v^{R *}}{d N}>0$ if population is below $\hat{N}(S)$, and $\frac{d v^{R *}}{d N}<0$ if population is above $\hat{N}(S)$.

Finally, note that $\tau^{*}-\frac{D^{\prime}\left(\theta^{*}\right)}{D^{\prime \prime}\left(\theta^{*}\right)}=\tau^{*}-\frac{Y(\hat{N})}{D^{\prime \prime}\left(\theta^{*}\right) \cdot A(S) \cdot X}=0$. This and $\frac{d \tau^{*}}{d S}<0$ (Result 2) and the assumptions $Y^{\prime}(\cdot)>0, D^{\prime \prime \prime}(\cdot) \leq 0$, and $A^{\prime}(\cdot)<0$ together imply that $\frac{d \hat{N}(S)}{d S}<0$.

The above analysis makes it clear that population growth and the resulting economic expansion have two opposing effects on the ruler's tax revenue (see Eq. 11). On one hand, it enlarges the tax base. On the other hand, it increases the rate of extralegal expropriation and reduces the fraction of the economic surplus that goes to the ruler. Result 4 shows that the latter effect begins to dominate the former once the population in the region crosses the threshold. What is more, it shows that the larger the dictatorship, the sooner the region reaches the tipping point where the negative effect of economic growth dominates the positive effect.

More generally, the following result holds:

Result 5 For any given $N$, economic expansion is less beneficial to the ruler in a larger dictatorship: $\frac{d}{d S}\left(\frac{d v^{R *}}{d N}\right)<0$.

Proof It follows from equation (11), $\frac{d \theta^{*}}{d S}>0$ (Result 1) and $\frac{d \tau^{*}}{d S}<0$ (Result 2), and the assumptions $D^{\prime \prime}(\cdot)>0$ and $D^{\prime \prime \prime}(\cdot) \leq 0$.

According to Result 5, at every population level $N$, the positive effect of economic growth on the ruler's revenue is always larger and the negative effect always smaller in a smaller dictatorship. In other words, the ruler in a larger dictatorship gains consistently less from the economic expansion due to greater agency costs.

Two dynamic outcomes For two dictatorships that differ significantly in size, the model predicts two distinct outcomes.

In the case of the small dictatorship, as its ruler is capable of capturing a significant portion of the economic surplus consistently (Results 2 and 5), he will invest relatively heavily in the

$34 D^{\prime \prime \prime}(\cdot) \leq 0$ is the key assumption (i.e., a sufficient condition) for Results 4 and 5 . As shown in the microfoundation provided in footnote 30 , it is satisfied when the ruler's information is sufficiently noisy. 


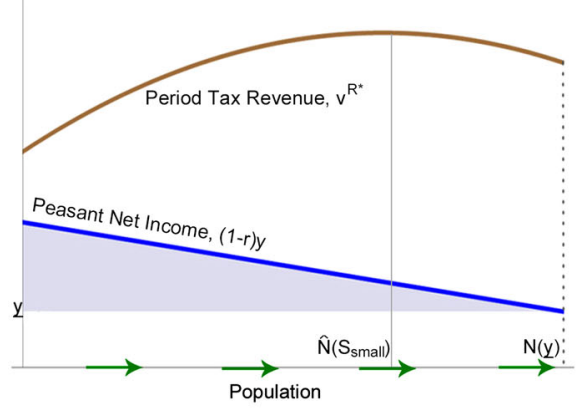

(a) Representative Region in Small Dictatorship

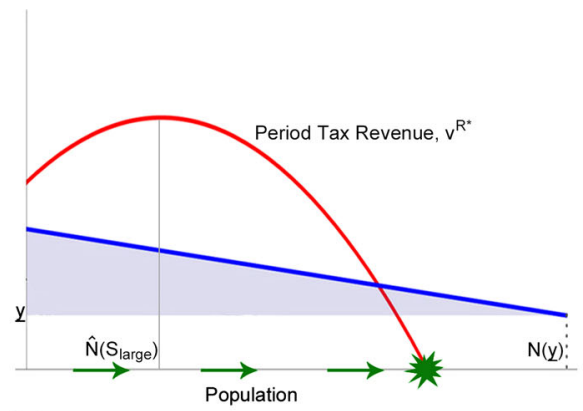

(b) Representative Region in Large Dictatorship

Fig. 5 Two dynamic outcomes

public good (Result 3) to protect the economy from periodic external shocks. In the absence of extraordinarily large shocks to disrupt the process, the population in every region that he governs will expand until per capita income falls to $\underline{y}$. At this point, the economy enters the steady state and will stay there unless a large exogenous shock knocks it out of that state (Fig. 5a).

The picture is different in the large dictatorship. In this case, the ruler's revenue begins to fall early while the economy still expands. As fiscal conditions worsen, the ruler cuts his investment in the public good. His regime could even go bankrupt before the economy enters the steady state. Here, we observe a clear pattern of dynastic rise and fall. The establishment of the dynasty brings order and stability initially, which allows economic expansion to take place. However, in a paradoxical manner, the regime finds itself increasingly incapable of managing the prosperity that it has helped create (Fig. 5b).

Our results affirm the conjecture in Usher (1989) that a society under despotic rule could either evolve into a stationary state or into a dynastic cycle. We show in the next section that the Tokugawa patterns match the stationary state scenario. The Japanese population grew steadily between 1600 and the early 1700 s, and stayed almost constant from then until 1850. The shogunate's revenue followed a similar path. By contrast, China saw an almost uninterrupted population expansion from the 1680s right up to 1850 . Yet the fiscal capacity of the Qing state began to contract in the first half of the 1700s in a manner that fits the second scenario.

\section{Empirical evidence}

Assuming that premodern China and Japan used similar production and monitoring technologies, our model predicts lower rates of corruption (Result 1), higher tax rates (Result 2), and higher levels of public goods provision per region (Result 3) in Tokugawa Japan than in Qing China. The model also predicts that, with economic expansion, the fiscal revenue in the shogunate would likely reach a steady state, while the revenue in China would hit its peak and begin to fall (Results 4 and 5).

In what follows, we assemble comparable quantitative data from primary and secondary sources to check these predictions. We first discuss the issue of corruption in China and Japan with respect to Result 1 . We then provide further evidence that Results 2, 4, and 5 are consistent with the fiscal and population patterns observed historically. Finally, we evaluate Result 3 by comparing the provision of key local public goods. 


\subsection{Corruption}

By its very nature, evidence of corruption is elusive. Nevertheless, consistent with our theoretical predictions, historical accounts by contemporary observers in Qing China suggest that bureaucratic corruption was pervasive during the eighteenth century and that it worsened over time. ${ }^{35}$ By comparison, the problem was reasonably contained in Tokugawa Japan.

As noted earlier, regional diversity in crops and multiple commutation rates across the empire made it difficult for the Chinese emperor to monitor local officials. In collecting land tax, over-collection (fu-shou) by magistrates and their underlings was reported to be endemic (Ch'u 1962; Zelin 1984). ${ }^{36}$

One popular form of over-collection was the manipulation of commutation rates, wherein magistrates demanded households to pay taxes in copper (instead of the officially stipulated silver or grain) and set the commutation rate above the market rate (Ch'u 1962, p. 142). Feng Guifen, a contemporary scholar, observed in the 1840s that commoners paid up to 16,000 wen of copper cash for every shi of rice that they owed in taxes, when the market price of rice was less than 3000 wen per shi (Wang 1973, p. 38). In Guangdong, the commutation rate increased by $250 \%$ (from 2 taels to 7 taels of silver per shi of grain) from the mid-eighteenth century to the mid-nineteenth century, even though the grain price rose only $40 \%$ during the same period (Lin 1997).

Setting a high commutation rate was just one example of over-collection. In Shanxi, 12 surtaxes unauthorized by the central government were imposed between 1735 and 1795 , followed by 7 additional items between 1796 and 1820 and 15 more between 1821 and 1850 (Wang 1973, p. 59).

According to Zhang (1962, p. 32), in the early nineteenth century a typical Chinese magistrate earned 30,000 silver taels a year through extralegal channels. By this estimate, the extralegal incomes of the 1,500 magistrates (45 million taels) would have exceeded the annual amount of tax silver that entered the state coffers (40 million taels in the early nineteenthcentury). Ni and Van (2006) estimate that corruption consumed more than $20 \%$ of China's agricultural output in 1850.

While bureaucratic corruption was a subject of intense discussion in official and scholarly discourse in Qing China, it attracted less attention in Tokugawa Japan. Political and intellectual elites in the late Tokugawa period were more concerned with the declining economic status of the ruling class (who served as government officials) than their misconduct (Jansen 1989; Totman 1993).

Bribes and gifts to tax officials were the common form of illegal exaction in Japan. However, historical accounts indicate that corruption was reasonably contained after the

\footnotetext{
35 Park (1997) suggests that corruption was already institutionalized in High Qing as it penetrated all levels of bureaucracy. The scale and frequency of corruption scandals increased significantly during the second half of the eighteenth century (Elliott 2009). The Qing emperors themselves became deeply concerned about the problem (Li 2007; Will 2008). For example, from the statements made by Emperor Daoguang (r. 1821-1850) in private interviews with officials, Will (2008) concludes that the emperor had a profound distrust of his bureaucracy.

36 To be sure, not all tax surcharges were illegal because some over-collection was necessary to cover the costs of tax collection. Emperor Kangxi (r. 1662-1722) once mentioned in private that he would consider a magistrate who imposed a $10 \%$ surcharge an honest official (Qu1962). Emperor Yongzheng (r. 1723-35) subsequently legalized the collection of a silver meltage fee to help pay for local administrative costs. The sanctioned rates averaged about $12 \%$ nationwide (Zelin 1984). Likewise in Japan, magistrates were initially allowed to collect a $3 \%$ surcharge on the regular rice tax to finance personnel and other expenses. During the 1720 s, the shogun Yoshimune instituted reforms to incorporate these expenses into the official budget. Our tax revenue estimates in Figs. 1 and 8 include these legal and informally approved surcharges.
} 
reforms in the 1680s (Nishizawa 2004, Chap. 2). For example, Teranishi Takamoto, a wellknown magistrate in the 1790 s, did extensive research and estimated that in a typical local jurisdiction of 50,000 koku, villagers spent about 500 ryo in bribing or entertaining the magistrate and his subordinates, which amounted to $1.0 \%$ of the agricultural output. ${ }^{37}$ Similarly, according to village records in the 1860 s, when petitioning for a tax reduction in the face of poor harvest, peasants in a village of 1,000 koku spent 13.6 ryo as gifts to tax officials who came for harvest inspection. This is equivalent to $1.6 \%$ of the village's total output. ${ }^{38}$ Case studies suggest that bribery of this scale was probably widespread and tolerated by the Japanese lords.

To obtain an upper bound estimate of corruption in Japan, we consider one of the worst corruption incidents that was uncovered and prosecuted by the shogunate (Matsuo 1995; Nishizawa 2004). In 1794, multiple villages in Osaka were found to have falsely obtained a tax reduction for harvest failure by bribing the local officials. Subsequently, 32 tax officials and 86 village leaders were charged with corruption and severely punished. Even in this case, the bribes constituted $12.8 \%$ of total output, ${ }^{39}$ which is considerably below Ni and Van's (2006) estimate of $20 \%$ in Qing China.

\subsection{Tax rate}

The model predicts a lower tax rate in the larger dictatorship (Result 2). It further predicts that tax rates will decline with population growth, but at a faster rate in the larger dictatorship. Assuming that per capita output was comparable between China and Japan, per capita tax revenue is a proxy for tax rate. As shown in Fig. 1, per capita tax revenue was consistently higher in the Tokugawa shogunate than in China. Furthermore, per capita tax revenue fell over time in both regimes but at a faster rate in China.

Intra-country comparisons within China as well as within Japan provide further evidence in support of Result 2. Sng (2014) has shown that the Qing state collected more taxes in regions closer to the capital where the imperial court could monitor the tax officials better. Although fiscal information on the smaller Japanese domains is fragmented, existing evidence suggests that tax rates were higher outside the shogunate (Nakabayashi 2012). Compared to an average tax rate of $34 \%$ in the Tokugawa shogunate, the lord of Aizu taxed his peasants at 50-55\% between 1637 and 1764 (Furushima 1963). In Choshu domain, agricultural outputs were taxed at an average rate of $40 \%$ in 1840 (Nishikawa 1985). As Fig. 6 illustrates, tax rates in Kumamoto were also higher than those in the shogunate (Miyamoto 2004; Hosokawa Hanseishi Kenkyuukai 1974). ${ }^{40}$

Importantly, unlike the case in early modern Europe where "war made the state and the state made war" (Tilly 1975), high tax rates in Japan were not driven by interstate competition. The Tokugawa era was one of extraordinary peace. In the two centuries after the Shimabara

\footnotetext{
37 The conversion rate was 1 ryo-koku in 1794 (Iwahashi 1981).

38 Assuming a $50 \%$ harvest failure in the village of 1,000 koku in Shinshu (2004, p. 202) and the conversion rate of 1.72 ryo-koku in Shinshu in 1863 (Iwahashi 1981) the share of the gifts in total production was $13.6 /(1720 \cdot 0.5)=0.0158$.

39 In one village of 196 koku in Osaka, magistrate assistants received 25 ryo during crop inspection to falsely report poor harvest (Matsuo 1995). Using the conversion rate of 1 ryo-koku in 1794 (Iwahashi 1981), the ratio of bribe to output was $25 / 196=0.1275$.

40 Due to data limitation, we are unable to compute per capita taxes in Aizu, Choshu, and Kumamoto. As such, we use official tax rates to compare the fiscal capacities of the shogunate and these domains. These official tax rates overstate the actual tax rates because of the way they were formulated. Since the tax assessment procedures were similar across domains, we assume that there is no systematic difference in the degree of overstatement of their official tax rates.
} 


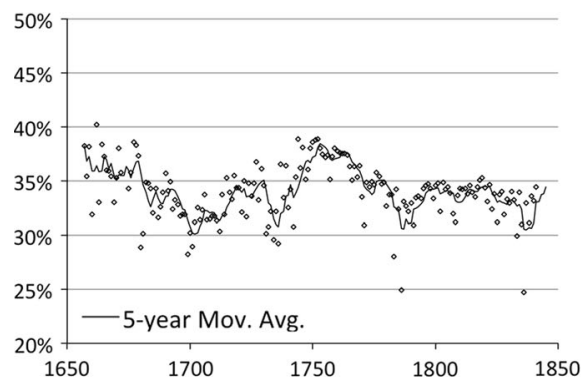

(a) Tokugawa shogunate

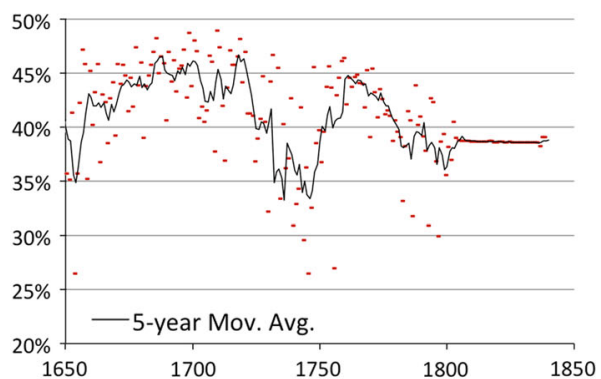

(b) Kumamoto domain

Fig. 6 Tax rate. Sources: Ohno (1996), Miyamoto (2004) and Hosokawa Hanseishi Kenkyuukai (1974)

rebellion (1637-1638), no major armed incident occurred. Until the West forced Japan to open up in the 1850s, tensions between the shogunate and local domains were never high enough to make war a real possibility.

\subsection{Population growth and fiscal change}

According to demographic trends, the Tokugawa era can be divided into two sub-periods. From 1600 to the early 1700 s, population grew from 12 million to 30 million and towns and cities proliferated. From 1700 to 1850 , however, Japan's population stayed at around 30 million (Fig. 7a). As Fig. 8a shows, aggregate tax revenue of the shogunate evolved in tandem with population change: land tax revenues grew steadily before the early eighteenth century and stayed more or less flat afterwards. ${ }^{41}$

In China proper, the population expanded steadily from the late 1600 s to around 1850 (Fig. 7b). However, the Qing state's tax revenue peaked in the first half of the eighteenth century and tailed off from then on (Fig. 8b). Ironically — but consistent with Result 4-the turning point occurred in the midst of the High Qing period, when the Chinese economy was expanding steadily and interregional trade was flourishing (Shiue and Keller 2007). ${ }^{42}$

According to Fig. 8, even though the Qing state collected lower taxes per capita, its aggregate tax revenue remained far greater than that of the Tokugawa shogunate throughout the period. If we assume that a ruler maximizes aggregate tax revenue and not per capita revenue, then it might have been perfectly rational for the Qing emperor to prefer to govern a large empire.

\subsection{Provision of local public goods}

Finally, we compare the provision of local public goods by the state in China and Japan. For our analysis, it is important to distinguish two categories of local public goods: local

\footnotetext{
41 The two dips in the shogunate land tax revenue after 1750 correspond to the Tenmei famine (1783-1786) and the Tenpo famine (1833-1837).

42 The decline in the Qing state's aggregate tax revenue in the early 1700 s coincided with two policy decisions. In 1712, Emperor Kangxi announced a permanent freeze on the head tax, which accounted for $5 \%$ of the national tax revenue, as it was found to be excessively regressive and prone to abuses in the collection process (Shi 2007). In the 1730s, the imperial court dropped its policy of incentivizing provincial and local officials to report newly reclaimed lands, as it became concerned that the policy had encouraged false reporting by officials who were eager to please the emperor, and peasants were made to shoulder taxes on lands that never existed (Rowe 2009). Given the political considerations behind these decisions, they are consistent with our argument.
} 


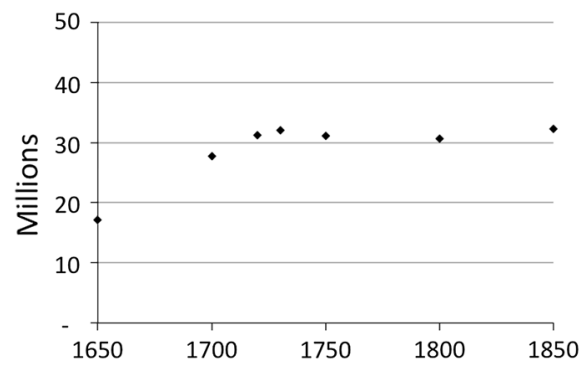

(a) Japan (Entire country)

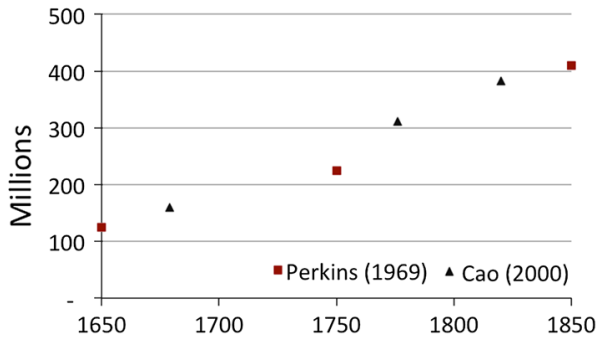

(b) China Proper

Fig. 7 Population. Sources: Hayami and Miyamoto (1988), Perkins (1969) and Cao (2000)

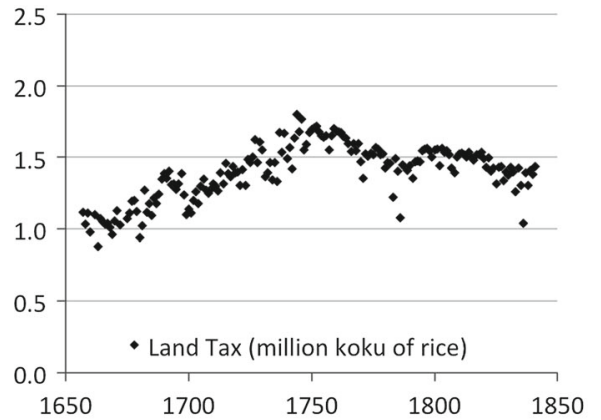

(a) Japan (Tokugawa shogunate only)

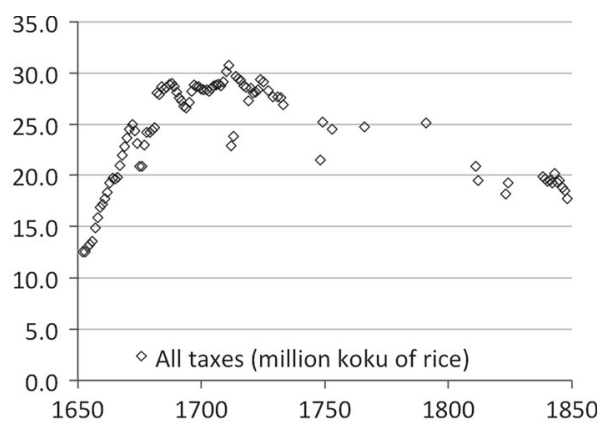

(b) China proper

Fig. 8 Aggregate tax revenue (Real). Sources: Ohno (1996) and Sng (2014)

public goods that serve (one or several) local communities and those that serve a wide region (or province). Historical studies indicate that in early modern China and Japan, much of the community-level local public goods, such as local roads and irrigation, were privately provided under the initiatives of local elites. ${ }^{43}$

By contrast, region-level local public goods, such as coinage and intercity transportation, require the involvement of the state to overcome coordination problems that arise from their greater scale of provision. Result 3 predicts that per capita provision of these public goods would be lower in Qing China than in the Tokugawa shogunate. In what follows, we compare state provision of the following local public goods in the two regimes: (a) coinage, (b) transportation network, (c) urban management, (d) forest protection, and (e) famine relief (Table 1).

\subsubsection{Coinage}

The circulation of quality, standardized coins helps to reduce the cost of everyday transactions. The Tokugawa shogunate produced gold, silver, and copper coins. The Chinese state minted copper coins only. In the absence of a reliable government-issued, large-denomination currency, the Chinese used silver bullion and foreign denominated silver coins for large trans-

43 In Qing China, the gentry played an important role in the construction and management of local projects such as bridges and dikes (Ch'u 1962, p. 182); in Tokugawa Japan, these local public goods were provided by the village (Nakane and Oishi 1990, pp. 45-59). 
Table 1 Public goods provision in Qing China and Tokugawa Japan

\begin{tabular}{lll}
\hline & China & Japan \\
\hline (a) Coinage & Copper only & Gold, Silver, Copper \\
Annual output of copper coins, aggregate & $3,639,800 \mathrm{k}(1756-65)$ & $1,096,000 \mathrm{k}(1764-88)$ \\
Annual output of copper coins, per capita & $15(1756-1765)$ & $35(1764-1788)$ \\
(b) Length of trunk roads (km) & 11,370 (imperial routes) & 1,440 (Gokaido) \\
Length per '00 sq. km & 0.26 & 0.51 or 3.37 \\
(c) Urban population (urbanization rate) & $20.5 \mathrm{~m}(5.8 \%)$ & $5.1 \mathrm{~m}(16.5 \%)$ \\
(d) Forest cover (million ha) & $18.5(1700) \rightarrow 9.6(1850)$ & $27(1600) \rightarrow 25.5(1850)$ \\
& $($ Lingnan region only) & \\
(e) Grain stockpile per capita (husked rice, koku) & $0.065(1751)$ & $0.038(1751)$ \\
& $\rightarrow 0.030(1843)$ & $\rightarrow 0.046(1843)$ \\
\hline
\end{tabular}

Sources: (1) Lin (2006) and Tsuchiya and Yamaguchi (1972); (2) DQHD (Yongzheng edition) and Vaporis (1994); (3) Rozman (1973, Table 5); (4) Saito (2009); (5) Eto (1970); Yoshida (1991); Wang (1985[1890]); Will and Wong (1991); Li and Jiang (2008)

actions. As Deng (2008) put it, "China's silver stock was made of a collage of pieces in just about all shapes, sizes and qualities under the sun."

Lin (2006) suggests that even in its heyday, the Qing state did not produce enough copper coins to satisfy the needs of its growing population. As a result, it had to tolerate the use of counterfeit coins to relieve currency scarcity. When the output of the Qing mints peaked between 1756 and 1765, national production reached 3,640 million pieces annually, or 15 copper coins per head. By comparison, the shogunate produced 1,096 million copper coins annually between 1764 and 1788 , or 35 pieces per head (Table 1a). ${ }^{44}$

\subsubsection{Transportation network}

The Tokugawa period witnessed the development of an extensive road network nationwide. The shogunate built a system of five major highways (Gokaido), centered on Edo (Fig. 3). Local lords, too, constructed roads and bridges to facilitate the flow of goods from rural areas to their castle towns (Yamamoto 1993). ${ }^{45}$

The shogunate also built a coastal transportation network to bring personnel and goods to Edo (Yamamoto 1993). Coastal waters were charted and lighthouses built to guide ships through the rocky coastline. In the 1670s, the shogunate established two shipping routes- the eastern sea circuit and the western sea circuit (Fig. 3) — which together formed a complete loop surrounding the main island of Honshu and lowered transport costs (Nakai and McClain 1998, pp. 164-5).

By contrast, the Chinese rulers did relatively little to improve its transport infrastructure. With the notable exception of trade along the Grand Canal, most long-distance trade was carried out among regions either well served by natural inland waterways or along the coast.

\footnotetext{
44 The shogunate monopolized coinage production in Japan. As such, we divide its coin output by the entire population of Japan instead of only the shogunate's population.

45 Historical accounts suggest that the quality of these roads was high by the standards of the day. The Swedish doctor Charles Thunberg observed in 1776 that "the roads in this country are broad, and furnished with two ditches, to carry off the water, and [are] in good order all the year round." On the eve of the Meiji Restoration, the Swiss envoy Aime Humbert commented that "compared with the great roads of Europe, the Tokaido is not the least bit inferior" (Vaporis 1994, pp. 39-44).
} 
Many roads appeared to be poorly built (Pomeranz 2000). Schran (1978) observes that "as a rule, the rivers and lakes were not made more passable for boats by the removal of obstacles such as rocks, silt, and debris, by the dredging or marking of channels, by the construction of two paths, etc," and "the Chinese people adapted to this limited involvement of the government in communication by 'struggling' on their own (individually or in groups) against the natural elements as well as each other."

In Table 1b, we use the length of trunk roads as a crude measure of state investment in transportation. The Qing imperial postal system, which the imperial court relied on to maintain communications with the rest of the country, was about 13,770 km long, or eight times the length of the Gokaido (Fig. 2). However, this implies a trunk road density (length divided by domain size, in $\mathrm{km}$ per $100 \mathrm{~km}^{2}$ ) of only 0.26 , compared to 3.37 in the shogunate if we assume that the Gokaido served only the shogunate domain. Even if we divide the length of the Gokaido by the whole of Japan, the resulting road density, at 0.51, would still be twice that of China. ${ }^{46}$

\subsubsection{Urban management}

The state played an active role in Japan's urban expansion. Local lords transformed their castles into towns as they strove to expand their tax base (McClain 1980). As these castle towns grew, their rulers imposed detailed regulations and devised new systems of urban administration (Nakai and McClain 1998). For example, after a big fire in 1657, the shogunate created open spaces in Edo to serve as fire breaks (Hanley 1987). Professional firefighting units were set up and watchtowers were built. ${ }^{47}$ Measures were also taken to ensure that waste materials were properly recycled or disposed of, and streets and waterways were kept clean and open in Edo as well as in the smaller towns and cities (Hanley 1987).

Contrary to Max Weber's claim that a heavy state presence in Chinese cities stifled China's economic development, formal administration penetrated far less in Chinese cities than in Japanese ones (Rozman 1973). Over $95 \%$ of the towns and cities in early modern China did not have a permanent bureaucratic presence (Zelin 2004). Unlike the case in Japan, where there was a distinction between the urban magistrates (machi-bugyō) and the rural ones (daikan), Chinese counties were not functionally differentiated into urban and rural units. ${ }^{48}$ The urban infrastructure in China was less developed than in Japan (Mosk 2011). A Chinese scholar observed in the early 1900s that "the hundred and one undertakings, such as roads, streetlights, removal of rubbish, water supply, school system, police, fire protection, etc., which people of the West are accustomed to regard as functions of a municipal government are, with a few exceptions of recent date, never undertaken by the proper government officials" (Rowe 1989, p. 135).

Rozman (1973) calculated that in 1800, Japan's urbanization rate (16.5\%) was more than twice that of China $(5.5 \%)$, and "the most urbanized province of China [Zhili] was considerably less urban than the least urbanized region of Japan [Tohoku]" (Table 1c). Some scholars have pointed out that conventional measures of urbanization may have underestimated China's true level of urbanization, for these measures overlook the proliferation of

\footnotetext{
46 The Chinese imperial postal system comprised both land and water routes. To obtain upper bound estimates for China, we treat them all as "roads."

47 According to Engelbert Kaempfer, a German physician who visited Japan between 1690 and 1692, it was common to see fire police patrolling the streets and equipment such as water-filled buckets and fire axes being placed at prominent intervals in Japanese cities (Kaempfer and Beatrice 1999).

48 See Mote (1973) and Fei (2009, pp. 13-20).
} 
small market towns in early modern China (Li 2000; Brandt et al. 2014). Our comparative analysis shows that the lack of state leadership in solving urban collective action problems may help to explain why, instead of seeing its largest cities growing, China's "urbanization" took such a unique path.

\subsubsection{Forest preservation}

Population growth and urbanization brought about rapid deforestation in seventeenth-century Japan. By the mid-seventeenth century, few prime forests were still in existence. Because environment degradation threatened the long-term economic and security interests of the shogun and local lords, they responded by issuing regulations to restrict entry into forests and clearance of woodland for cultivation. Over time, they created new administrative bodies (e.g., the Kinai Office of Erosion Control) and positions (e.g., forest magistrates) to enforce the regulations, demanded the compilation of forest registers to track illegal logging, set up inspection points along rivers and roads to detect smugglers, and implemented sumptuary rules to prohibit the use of precious timber on "wasteful" activities. ${ }^{49}$ Attempts were also made to delineate the boundaries between domains as well as between villages to avoid "the tragedy of commons." Finally, the shogunate and some domains promoted reforestation programs actively (Totman 1989).

Early modern China, too, experienced rapid deforestation (Elvin and Liu 1998; Elvin 2004; Marks 2012). Like the Japanese rulers, the Qing emperor was acutely aware of the problem and the threat it posed to social stability. When flash floods caused by excessive land reclamation plagued the middle reaches of the Yangzi River in the second half of the eighteenth century, the state intervened spontaneously. However, its efforts were thwarted by corruption and inefficient administration. Zhang (2006, p. 100) observes that the government's attempt to issue new regulations and throw resources at the problem was unsuccessful and "money was wasted on a top-heavy, inefficient, and corrupt bureaucracy." 50 According to McCaffrey (2003), the Qing state's inability to manage the rivalry among local communities in the region was a major contributing factor to the White Lotus Rebellion in 1796.

Saito (2009) provides a quantitative measure to compare environmental preservation outcomes in China and Japan. Between 1600 and 1850, the estimated woodland area in Japan fell from 27 million hectares to 25.5 million hectares, and the movement between the two time points followed a U-shaped trajectory: forest cover first contracted sharply before rebounding. In Lingnan, a region in South China that "share[d] much the same flora and climate" as Japan, forest-covered area was almost halved from 18.3 million hectares in 1700 to 9.6 million hectares in 1850 (Table 1d).

\subsubsection{Famine relief}

For agrarian societies, crop failures could undermine social stability. To mitigate this threat, the Qing emperors built a nationwide system of public granaries known as the ever-normal granaries. Located in the provincial, prefectural, and county capitals, these granaries were managed by the local magistrates and were expected to perform two main functions: famine relief in natural disasters and price smoothing in normal times (buying low and selling high) (QSG, 1976 [1927], juan 121).

\footnotetext{
49 For example, in 1706, the shogunate banned the use of large pine trees as New Year's decorations.

50 Similar situations were observed elsewhere. In the Hunan province, Perdue (1987) argues that it was not a lack of awareness of the problem but "the state's limited impact on the society" that doomed the Qing government's efforts to reverse the trend of ecological degradation there.
} 
The size and frequency of the Qing state's granary operations reached a peak in the mideighteenth century, and by the 1780s, the system was on a path of decline (Will and Wong 1991). Corruption was considered to be a main factor. In 1781, a major embezzlement case was exposed in the northwestern province of Gansu, where provincial officials conspired to falsely report droughts and carry out phantom relief operations. In 1792, when Emperor Qianlong instructed the governor-general of Zhili to provide relief to famine-stricken areas, he found out that the province's reported grain reserve was grossly inflated and it had no capacity to execute his order (QSL, QL juan 1417).

In Japan, the shogunate established a nationwide system of rice stockpile in 1633 in which a fixed amount of rice was stored in over 50 castles in various domains for military and emergency purposes (Yanagitani 1985, 1989). During the Kyoho famine in 1732, the shogunate used this system to send a large volume of rice to disaster areas and successfully contained the damage (Yanagitani 1985; Kikuchi 1997). The same system, however, proved inadequate in coping with the much greater Tenmei famine from 1783 to 1786, which resulted in heavy casualties in the northern domains and major riots in Edo and Osaka. Not to repeat the dismal experience, the shogunate set up nonmilitary granaries modeled after China and (1) ordered magistrates to create village granaries and store $0.1 \%$ of rice output $(0.2 \%$ of other grains) throughout the shogunate domain; (2) established ever-normal granaries in major cities; and (3) ordered local lords to build granaries in their domains and store $2.5 \%$ of rice output (Ando 2000)..$^{51}$

The new granaries complemented the existing ones and played a major role in mitigating the impact of the Great Tempo Famine from 1832 to 1837, especially in Edo (Yoshida 1991; Kikuchi 1997). Right after the famine, the shogunate ordered local lords to stock an additional $2.5 \%$ of rice output in their granaries (Ando 2000).

The shogunate made periodic inspections to monitor the amount of rice in the castle and city granaries. Although the actual amount often fell short of the stipulated amount due to high maintenance and replenishment costs, corruption did not appear to be a major problem. Ando (2000) reports corruption cases in Edo involving town leaders overstating the number of needy households to misappropriate money, but the degree of overstatement was meager. Although data are scarce, our estimates indicate that the amount of emergency reserve increased steadily from 1750 to 1850 in Japan, reflecting the successive reforms. In the shogunate domain, the amount of reserve, measured in husked rice, grew from less than $300,000 \mathrm{koku}$ in 1751 to $368,000 \mathrm{koku}$ in 1843 , and to $555,000 \mathrm{koku}$ in 1861 ; in per capita terms, it rose from less than 0.038 koku in 1751 to 0.046 koku in 1843 , and to 0.068 koku in 1861 (Table 1e)..$^{52}$

In China, the amount of grain stockpiles in public granaries increased initially from 14.7 million koku in 1751 to 17.0 million koku in 1782, but declined subsequently to 11.9 million

\footnotetext{
51 Many local lords also instituted various forms of granaries through their own initiatives (Kikuchi 1997).

52 These estimates are derived using the following data and assumptions. The amount of rice reserves is a sum of (1) rice stockpiles in the shogunate domain (bakuryo shirozume-mai), (2) the shogunate-funded portion of village granaries (gokura), and (3) the city granaries (machikaisho) in Edo and Osaka funded primarily by the shogunate. Data for 1751 are based on Yanagitani (1985) and Iijima (2004). Data for 1843 are drawn from historical record, Zenkoku Chokoku Aridaka, reproduced in Eto (1970), and from Yoshida (1991). Data for 1861 are drawn from the historical document, Okinginkome Aridaka Kakitsuke, reproduced in Ohno (2008), as well as from Yoshida (1991) and Iijima (2004). To produce lower bound estimates, we assume that the rice reserves in the shogunate domain served not only the shogunate domain, but also the fiefs of his vassals (hatamoto). We further assume that the population of the shogunate domain and vassal territories made up $25 \%$ of the total population in Japan. Granaries were held in the form of husked rice (kome) as well as unhusked rice (momi), grains, and cash. We only include rice in our estimates to be conservative and use the standard rate of 0.5 to convert unhusked rice into husked rice.
} 
koku in 1843, and to 10.3 million koku in 1850. In per capita terms, it declined from 0.065 koku in 1751 to $0.060 \mathrm{koku}$ in 1782, and fell further to 0.030 koku in 1843 and to $0.025 \mathrm{koku}$ in $1850 .{ }^{53}$

In other words, while the Qing emperor had higher capacity to provide famine relief than the Tokugawa shogun in the mid-eighteenth century, their positions were reversed by the mid-nineteenth century, which is consistent with our theoretical predictions. ${ }^{54}$

\section{Conclusion}

In this paper, we provide a comparative and historical institutional analysis of state capacity in Qing China and Tokugawa Japan. We show that despite a common cultural, institutional, and technological heritage, there was already a fiscal divergence between China and Japan before their first attempts at modernization in response to the arrival of the West.

Theoretically and empirically, we demonstrate that the extraordinary geographical size of China imposed increasingly insurmountable constraints on the regime's capacity to collect taxes and provide essential local public goods as its economy expanded. ${ }^{55}$ It is our conjecture that this factor alone might have been sufficient in holding back China's transition from stagnation to growth even in the absence of Western imperialism. ${ }^{56}$

By contrast, aided partly by Japan's geographical compactness, the Tokugawa shogunate and the local lords were able to perform basic functions and thereby maintain social order up until the arrival of the Black Ships. ${ }^{57}$ Although the shogunate was replaced by a coalition of powerful local lords during the Meiji Restoration, the new government inherited from the Tokugawa period an established system of political controls and a functioning tax system

\footnotetext{
53 We arrive at the estimates for China based on the following data and assumptions. The amount of grain reserves is the sum of grain stockpiled in (1) nonmilitary state granaries outside Beijing, (2) state granaries in Beijing, and (3) military granaries. Data for (1) are drawn from Will and Wong (1991, Table A.2), and (2) from Li and Jiang (2008). For (3), due to the paucity of historical data, we derive our estimates based on the following assumptions: the Wenzhou standard of storing 2 shi of unhusked rice per soldier (Wang 1890) was observed nationally; the Qing military stood at 800,000 soldiers throughout the period considered. Because rice was the most valuable grain, to obtain an upper bound estimate we assume that all grains in the granaries were rice.

54 Accounting for the likelihood that the nineteenth-century Chinese figures were over-reported by the local officials would only strengthen our result.

55 We focus on agency problems as the primary mechanism that links geography and state capacity. There may be other geography-induced factors that impact state capacity. If these factors had a strong and increasingly differential influence on state capacity in China and Japan, the empirical importance of our theoretical findings may be weakened.

56 Importantly, the frequency and scale of violent peasant uprisings in China escalated from the 1770s onward due to weakening social control (Naquin and Rawski 1987; Sng 2014). The first large-scale commoner uprising in Qing China, the Lin Shuangwen Uprising of 1786, preceded the Opium War (1839-42) by half a century and two of the subsequent major uprisings also took place before the Western intrusion (i.e., the White Lotus Rebellion of 1796 and the Eight Trigrams Uprising of 1813). Furthermore, the Opium War was dwarfed by the Taiping Rebellion (1850-64) in terms of duration and scale. An estimated twenty million lives were lost in the rebellion (Ho 1959), which was suppressed only after the central government ceded political power to provincial governors and the gentry.

57 The Tokugawa shogunate maintained 215 years of uninterrupted domestic peace from the Shimabara Rebellion in 1638 to the arrival of the Black Ships in 1856. To be sure, the incidents of peasant riots ( $\mathrm{ikki}$ ) also increased in Tokugawa Japan after 1700, but these "riots" were unarmed and well-ordered peasant protests and violent confrontations rarely happened except during the early Tokugawa years (Vaporis 1994; Hosaka 2006).
} 
that provided the newly established state with a sizable fraction of the national income from the onset (Sakane 2011a, b; Nakabayashi 2012).

It is often argued that the paths of China and Japan diverged after 1868 due to the rise of a more effective government in Japan (Beasley 1972; Ma 2004). In this paper, we show that the divergence of their state capacity was well underway before 1850. In light of recent findings on the importance of a proactive state in facilitating the transition from stagnation to growth (Doepke 2004; Galor et al. 2009; Dincecco and Prado 2012), we conjecture that Tokugawa Japan's legacy of a strong state might have prepared Japan better for the age of industrialization. In other words, we see the proactive Meiji government as a product of Japan's history, not a radical break from the past.

Acknowledgments This paper was previously circulated under the title "Taxation and Public Goods Provision in China and Japan before 1850." We thank Joel Mokyr for his encouragement and suggestions. Stephen Broadberry, Phil Hoffman, Michihiro Kandori, Mark Koyama, Takashi Kurosaki, Masaki Nakabayashi, Jared Rubin, Takashi Shimizu, Yasuo Takatsuki, Se Yan, Chun-Lei Yang, the editor, four anonymous referees, and seminar participants at Rutgers University, UC Irvine, Caltech, Osaka University, Hitotsubashi University, University of Tokyo, University of Hawaii, Peking University Guanghua School of Management, UC Berkeley, Stanford University, the 2012 Econometrics Society North American Summer Meeting, the 2012 Asian Historical Economics Conference, the 2012 Hong Kong Economic Association Conference, and the 2013 ASSA Meeting provided many helpful comments. We gratefully acknowledge financial support from the JSPS Grant-in-Aid for Scientific Research (S) 22223003.

\section{References}

Acemoglu, D. (2005). Politics and economics in weak and strong states. Journal of Monetary Economics, 52(7), 1199-1226.

Alcock, R. (1863). The capital of the tycoon: A narrative of a three years' residence in Japan. London: Longman, Green, Longman, Roberts \& Green.

Alesina, A., \& Spolaore, E. (1997). On the number and size of nations. Quarterly Journal of Economics, 112(4), 1027-1056.

Allen, R. C., Bassino, J. P., Ma, D., Moll-Murata, C., \& van Zanden, J. L. (2011). Wages, prices, and living standards in China, 1738-1925: In comparison with Europe, Japan, and India. Economic History Review, 64(s1), 8-39.

Ando, Y. (2000). Kansei Kaikakuki no Toshi Seisaku [Urban Policies in the Kansei Reform Period]. Tokyo: Azekura Shobo.

Aoki, M. (2014). Strategies and public propositions in games of institutional change: Theory and comparative historical cases, available at SSRN: http://ssrn.com/abstract=2445628. Accessed 05 Sept 2014.

Ashraf, Q., \& Galor, O. (2013). The 'Out of Africa' hypothesis, human genetic diversity, and comparative economic development. American Economic Review, 103(1), 1-46.

Balazs, E. (1964). Chinese civilization and bureaucracy: Variations on a theme. New Haven: Yale University Press.

Baten, J., Ma, D., Morgan, S., \& Wang, Q. (2010). Evolution of living standards and human capital in China in the 18-20th centuries: Evidences from real wages, age-heaping, and anthropometrics. Explorations in Economic History, 47(3), 347-359.

Beasley, W. G. (1972). The Meiji restoration. Stanford: Stanford University Press.

Besley, T., \& Persson, T. (2009). The origins of state capacity: Property rights, taxation, and politics. American Economic Review, 99(4), 1218-44.

Besley, T., \& Persson, T. (2013). Taxation and development. In A. J. Auerbach, R. Chetty, M. Feldstein, E. Saez (Eds.), Handbook of public economics (Vol. 5, pp. 51-110). Amsterdam: Elsevier.

Brandt, L., Ma, D., \& Rawski, T. (2014). From divergence to convergence: Re-evaluating the history behind China's economic boom. Journal of Economic Literature, 52(1), 45-123.

Broadberry, S. (2013). Accounting for the great divergence, LSE Economic History Working Papers, 184/2013.

Campante, F. R., \& Do, Q. A. (2014). Isolated capital cities, accountability, and corruption: Evidence from US states. American Economic Review, 104(8), 2456-81.

Cao, S. J. (2000). Zhongguo Ren Kou Shi [The Demographic History of China]. Shanghai: Fudan Press.

Ch'u, T. T. (1962). Local government in China under the Ch'ing. Cambridge, MA: Harvard University Press. 
Deng, K. (2008). Miracle or mirage? Foreign silver, China's economy and globalization from the sixteenth to the nineteenth centuries. Pacific Economic Review, 13(3), 320-357.

Dincecco, M. (2011). Political transformations and public finances: Europe, 1650-1913. Cambridge, MA: Cambridge University Press.

Dincecco, M., \& Katz, G. (2014). State capacity and long-run economic performance. Economic Journal (forthcoming).

Dincecco, M., \& Prado, M. (2012). Warfare, fiscal capacity, and performance. Journal of Economic Growth, 17(3), 171-203.

Dincecco, M., Federico, G., \& Vindigni, A. (2011). Warfare, taxation, and political change: Evidence from the Italian Risorgimento. Journal of Economic History, 71(4), 887-914.

Doepke, M. (2004). Accounting for fertility decline during the transition to growth. Journal of Economic Growth, 9(3), 347-383.

Doepke, M., \& Zilibotti, F. (2005). The macroeconomics of child labor regulation. American Economic Review, 95(5), 1492-1524.

DQHD. (2006). Da Qing wuchao huidian [Collected Statutes of the Qing Dynasty through Five Reigns]. Beijing: Thread-binding Books Publishing House.

Elliott, M. (2009). Emperor Qianlong: Son of heaven, man of the world. New York: Pearson Longman.

Elvin, M. (2004). The retreat of the elephants: An environmental history of China. New Haven, CT: Yale University Press.

Elvin, M., \& Liu, T. J. (1998). Sediments of time: Environment and society in Chinese history. Cambridge, MA: Cambridge University Press.

Eto, J. (Ed.). (1970). Katsu Kaishu Zenshu [Complete Works of Kaishu Katsu] (Vol. 3). Tokyo: Keiso Shobo.

Fang, Q. (2009). Hot potatoes: Chinese complaint systems from early times to the late Qing (1898). Journal of Asian Studies, 68(4), 1105-1135.

Fei, S. (2007). We must be taxed: A case of populist urban fiscal reform in Ming Nanjing (1368-1644). Late Imperial China, 28(2), 1-40.

Fei, S. (2009). Negotiating urban space: Urbanization and late Ming Nanjing. Cambridge, MA: Harvard University Asia Center.

Feuerwerker, A. (1976). State and society in eighteenth-century China: the Ch'ing Empire in its glory. Ann Arbor, MI: Center for Chinese Studies, University of Michigan.

Furushima, T. (1963). Shohin ryutsu no hatten to ryoshu keizai [The lord's economy and the development of commerce]. In S. Ienaga (Ed.), Iwanami Koza Nihon Rekishi [Iwanami Lectures on Japanese History] (Vol. 12). Tokyo: Iwanami Shoten.

Galor, O. (2005). From stagnation to growth: Unified growth theory. In P. Aghion \& S. Durlauf (Eds.), Handbook of economic growth (pp. 171-293). Amsterdam: Elsevier.

Galor, O. (2011). Unified growth theory. Princeton, NJ: Princeton University Press.

Galor, O., \& Moav, O. (2006). Das Human-Kapital: A theory of the demise of the class structure. Review of Economic Studies, 73(1), 85-117.

Galor, O., Moav, O., \& Vollrath, D. (2009). Inequality in landownership, the emergence of human-capital promoting institutions, and the great divergence. Review of Economic Studies, 76(1), 143-179.

Gennaioli, N., \& Voth, H.J. (2011). State capacity and military conflict, CEPR Discussion Paper No. DP8699.

Giroud, X. (2013). Proximity and investment: Evidence from plant-level data. Quarterly Journal of Economics, $128(2), 861-915$.

Greif, A. (1998). Historical and comparative institutional analysis. American Economic Review, 88(2), 80-84.

Grossman, S., \& Hart, O. (1986). The costs and benefits of ownership: A theory of vertical and lateral integration. Journal of Political Economy, 94(4), 691-719.

Hanley, S. B. (1987). Urban sanitation in preindustrial Japan. Journal of Interdisciplinary History, 18(1), 1-26.

Hansen, G., \& Prescott, E. (2002). Malthus and Solow. American Economic Review, 92(4), 1205-1217.

Hayami, A., \& Miyamoto, M. (1988). Nihon Keizaishi: Keizai Shaki no Seiritsu, 17-18 Seiki [Emergence of Economic Society, 17 and 18th Centuries]. Tokyo: Iwanami Shoten.

He, W. (2013). Paths toward the modern fiscal state: England, Japan, and China. Cambridge, MA: Harvard University Press.

Heijdra, M. (1998). The socio-economic development of rural China under the Ming. In D. Twitchett \& F. W. Mote (Eds.), The Cambridge history of China. Vol. 8: The Ming dynasty, 1368-1644 (pp. 417-578). Cambridge, MA: Cambridge University Press.

Ho, P. T. (1959). Studies on the population of China, 1368-1953. Cambridge, MA: Harvard University Press.

Hoffman, P. T., \& Rosenthal, J. L. (1997). The political economy of warfare and taxation in early modern Europe: Historical lessons for economic development. In J. Drobak \& J. Nye (Eds.), The frontiers of the new institutional economics (pp. 31-55). St. Louis, MO: Academic Press. 
Hosaka, S. (2006). Hyakusho Ikki to Gimin no Kenkyu [Research on Peasant Riots and Martyrs]. Tokyo: Yoshikawa Kobunkan.

Hosokawa Hanseishi Kenkyuukai (1974). Kumamoto-han Nenpyo Ko [A Draft Chronology of Kumamoto domain]. Kumamoto.

Huang, P. C. C. (2003). Further thoughts on eighteenth-century Britain and China: Rejoinder to Pomeranz's response to my critique. Journal of Asian Studies, 62(1), 157-187.

Huang, R. (1974). Taxation and governmental finance in sixteenth-century Ming China. London: Cambridge University Press.

Iijima, C. (2004). Edo Bakufu Zaisei no Kenkyu [Research on Edo Bakufu Finance]. Tokyo: Yoshikawa Kobunkan.

Iwahashi, M. (1981). Kinsei Nihon Bukkashi no Kenkyu: Kinsei Beika no Kozo to Hendo [Studies on Commodity Prices in Early Modern Japan: The Structure and Transformation of Early Modern Rice Prices]. Tokyo: Ohara Shinseisha.

Jansen, M. (Ed.). (1989). The Cambridge history of Japan, volume 5: The nineteenth century. Cambridge: Cambridge University Press.

Jansen, M. (1992). China in the Tokugawa World. Cambridge, MA: Harvard University Press.

Johnson, N. D., \& Koyama, M. (2014a). Tax farming and the origins of state capacity in England and France. Explorations in Economic History, 51, 1-20.

Johnson, N. D., \& Koyama, M. (2014b). Taxes, lawyers, and the decline of witch trials in France. Journal of Law \& Economics, 57(1), 77-112.

Jones, E. (1981). The European miracle: Environments, economies, and geopolitics in the history of Europe and Asia. Cambridge, MA: Cambridge University Press.

Kaempfer, E., \& Beatrice, M. B. B. (1999). Kaempfer's Japan: Tokugawa culture observed. Honolulu: University of Hawaii Press.

Kikuchi, I. (1997). Kinsei no Kikin [Famines in Premodern Japan]. Tokyo: Yoshikawa Kobunkan.

Kiser, E., \& Tong, X. (1992). Determinants of the amount and type of corruption in state fiscal bureaucracies: An analysis of late imperial China. Comparative Political Studies, 25(3), 300-331.

Ko, C. Y., \& Sng, T. H. (2013). Regional dependence and political centralization in imperial China. Eurasian Geography and Economics, 54(5-6), 470-483.

Ko, C.Y., Koyama, M., \& Sng, T.H. (2014). Unified China and divided Europe, available at SSRN: http://ssrn. com/abstract=2382346. Accessed 05 Sept 2014.

Landes, D. S. (1998). The wealth and poverty of nations: Why some are so rich and some so poor. New York: W.W. Norton.

Levi, M. (1988). Of rule and revenue. Berkeley, CA: University of California Press.

Li, B. (2000). Jiangnan de Zaoqi Gongyehua (1550-1850) [Jiangnan's Early Industrialization, 1550-1820]. Beijing: Social Sciences Documentation Press.

Li, L. M. (2007). Fighting famine in North China: State, market, and environmental decline, 1690s-1990s. Stanford, CA: Stanford University Press.

Li, W. Z., \& Jiang, T. X. (2008). Qingdai Caoyun [The Grain Tribute System of Qing Dynasty]. Beijing: Social Sciences Academic Press.

Lin, A. (1997). The rural economy of Guangdong, 1870-1937: A study of the Agrarian crisis and its origins in Southernmost China. New York: St. Martin's Press.

Lin, M. H. (2006). China upside down: Currency, society, and ideologies, 1808-1856. Cambridge, MA: Harvard University Asia Center.

Ma, D. (2004). Why Japan, not China, was the first to develop in East Asia: Lessons from sericulture, 18501937. Economic Development and Cultural Change, 52(2), 369-394.

Ma, D. (2011). Rock, scissors, paper: The problem of incentives and information in traditional Chinese state and the origin of great divergence, LSE Economic History Working Paper, 152/11.

Maddison, A. (2001). The world economy: A millennial perspective. Paris: OECD.

Marks, R. (2012). China: Its environment and history. Lanham, MD: Rowman \& Littlefield Publishers.

Matsuo, H. (1995). Kanseiki kinai bakuryo ni okeru zoshuuwai to sono shobatsu [Bribery and its punishment in the shogunate during the Kansei period]. In N. Asao (Ed.), Nihon Kokka no Shiteki Tokushitsu [Historical Characteristics of the Japanese State]. Tokyo: Shibunkaku Shuppan.

McCaffrey, C. M. (2003). Living through rebellion: A local history of the White Lotus Uprising in Hubei, China. Dissertation, University of California, San Diego.

McClain, J. L. (1980). Castle towns and daimyo authority: Kanazawa in the years 1583-1630. Journal of Japanese Studies, 6(2), 267-299.

Mencius, (2004). Mencius. London: Penguin Books. translated by D. C. Lau.

Miyamoto, M. (2004). Prices and macroeconomics dynamics. In A. Hayami, O. Saito, \& R. Toby (Eds.), Emergence of economic society in Japan, 1600-1870 (pp. 119-158). Oxford: Oxford University Press. 
Mosk, C. (2011). Traps embraced or escaped: Elites in the economic development of modern Japan and China. Singapore: World Scientific.

Mote, F. W. (1973). A millennium of Chinese urban history: Form, time, and space concepts in Soochow. Rice University Studies, 59(4), 35-65.

Nakabayashi, M. (2012). Rise of the Japanese fiscal state. In B. Yun-Casalilla, P. O'Brien, \& F. Comin Comin (Eds.), The rise of fiscal states: A global history, 1500-1914 (pp. 378-409). Cambridge, MA: Cambridge University Press.

Nakai, N., \& McClain, J. L. (1998). Commercial change and urban growth in early modern Japan. In M. Smitka (Ed.), The Japanese economy in the Tokugawa Era (pp. 131-207). New York: Garland Pub.

Nakane, C., \& Oishi, S. (1990). Tokugawa Japan: The social and economic antecedents of modern Japan. Tokyo: University of Tokyo Press.

Naquin, S., \& Rawski, E. (1987). Chinese society in the eighteenth century. New Haven, CT: Yale University Press.

Ni, S., \& Van, P. H. (2006). High corruption income in Ming and Qing China. Journal of Development Economics, 81(2), 316-336.

Nishikawa, S. (1985). Nihon Keizai no Seichoshi [History of the Growth of the Japanese Economy]. Tokyo: Toyo Keizai.

Nishizawa, A. (1998). Bakuryo Jinya to Daikan Shihai [Magistrates' Offices and Controls]. Tokyo: Iwata Shoin.

Nishizawa, A. (2004). Daikan no Nichijo Seikatsu [Everyday Life of Magistrates]. Tokyo: Kodansha.

O'Brien, P. (2005). Fiscal and financial preconditions for the rise of British naval hegemony: 1485-1815, LSE Economic History Working Paper, 91/05.

Ocko, J. (1988). I'll take it all the way to Beijing: Capital appeals in the Qing. Journal of Asian Studies, 47(2), 291-315.

Ohira, Y. (2003). Meyasubako no Kenkyu [A Study of the Petition Box]. Tokyo: Sobunsha.

Ohno, M. (1996). Edo Bakufu Zaiseishi Ron [Financial History of Edo Shogunate]. Tokyo: Yosikawa Kobunkan.

Ohno, M. (2008). Edo Bakufu Zaisei Shiryo Shusei [Collections of Historical Documents on the Tokugawa Shogunate Finance] (Vol. 1). Tokyo: Yoshikawa Kobunkan.

Olson, M. (1993). Dictatorship, democracy, and development. American Political Science Review, 87(3), 567-576.

Olsson, O., \& Hansson, G. (2011). Country size and the rule of law: Resuscitating Montesquieu. European Economic Review, 55(5), 613-629.

Park, N. (1997). Corruption in eighteenth-century China. Journal of Asian Studies, 56(4), 967-1005.

Perdue, P. C. (1987). Exhausting the earth: State and peasant in Hunan, 1500-1850. Cambridge, MA: Harvard University Press.

Perkins, D. H. (1969). Agricultural development in China, 1368-1968. Chicago: Aldine.

Pomeranz, K. (2000). The great divergence: China, Europe, and the making of the modern world economy. Princeton, NJ: Princeton University Press.

QSG. (1976[1927]). Qing Shi Gao [Draft History of the Qing]. Beijing: Zhonghua Shuju. compiled by Zhao Erxun [1844-1927].

QSL. (1986). Qing Shilu [Veritable Records of the Qing dynasty]. Beijing: Zhonghua Shuju.

Reischauer, E. (1970). Japan: The story of a nation. London: Duckworth.

Roberts, L. (1994). The petition box in eighteenth-century Tosa. Journal of Japanese Studies, 20(2), 423-458.

Rosenthal, J. L., \& Wong, R. B. (2011). Before and beyond divergence: The politics of economic change in China and Europe. Cambridge, MA: Harvard University Press.

Rowe, W. (1989). Hankow: Conflict and community in a Chinese city, 1796-1895. Stanford, CA: Stanford University Press.

Rowe, W. (2009). China's last empire: The great Qing. Cambridge, MA: Harvard University Press.

Rozman, G. (1973). Urban networks in Ch'ing China and Tokugawa Japan. Princeton, NJ: Princeton University Press.

Saito, O. (2009). Forest history and the great divergence: China, Japan, and the west compared. Journal of Global History, 4(3), 379-404.

Sakane, Y. (2011a). Ie to Mura: Nihon Dento Shakai to Keizai Hatten [House and Village: Traditional Japanese Society and Economic Development]. Tokyo: Nobunkyo.

Sakane, Y. (2011b). Kindai nihon ni okeru chozei seido no tokushitsu [The characteristics of the tax collection system in early modern Japan]. In M. Katsube (Ed.), Kindai Higashi Ajia ni okeru Gairai to Zairai [The Foreign and the Native in Premodern East Asia] (pp. 385-472). Osaka: Seibundo Shuppan.

Schran, P. (1978). A reassessment of inland communications in late Ch'ing China. Late Imperial China, 3(10), $28-48$. 
Shi, Z. (2007). Dingyin zhi zheng yu tandingrudi [The collection of the head tax and the apportionment of the head tax quota into the land tax]. Qingshi luncong [Symposium on Qing history] (pp. 148-160). Beijing: CASS.

Shiue, C. H., \& Keller, W. (2007). Markets in China and Europe on the eve of the industrial revolution. American Economic Review, 97(4), 1189-1216.

Sng, T.H. (2014). Size and dynastic decline: The principal-agent problem in late imperial China. Explorations in Economic History (forthcoming).

Stasavage, D. (2011). States of credit: Size, power, and the development of European polities. Princeton, NJ: Princeton University Press.

Tilly, C. (1975). Reflections on the history of European state-making. In C. Tilly (Ed.), The formation of national states in Western Europe (pp. 3-83). Princeton, NJ: Princeton University Press.

Totman, C. (1967). Politics in the Tokugawa Bakufu, 1600-1843. Cambridge, MA: Harvard University Press.

Totman, C. (1989). The green archipelago: Forestry in preindustrial Japan. Berkeley, CA: University of California Press.

Totman, C. (1993). Early modern Japan. Berkeley, CA: University of California Press.

Tsuchiya, T., \& Yamaguchi, K. (1972). Zuroku Nihon No Kahei [Japanese Currency Illustrated]. Tokyo: Toyo Keizai Shinposha.

Usher, D. (1989). The dynastic cycle and the stationary state. American Economic Review, 79(5), 1031-1044.

Vaporis, C. (1994). Breaking barriers: Travel and the state in early modern Japan. Cambridge, MA: Council on East Asian Studies, Harvard University.

Walthall, A. (1991). Peasant uprisings in Japan: A critical anthology of peasant histories. Chicago: University of Chicago Press.

Wang, Q. (1985[1890]). Shiqu Yu Ji [Collection of Notes on Fiscal Matters of the Qing Dynasty]. Beijing: Beijing Ancient Books Publishing House.

Wang, Y. C. (1973). Land taxation in imperial China, 1750-1911. Cambridge, MA: Harvard University Press.

Wang, Y. C. (1992). Secular trends of rice prices in the Yangzi Delta, 1638-1935. In T. G. Rawski \& L. M. Li (Eds.), Chinese history in economic perspective (pp. 35-68). Berkeley, CA: University of California Press.

Watt, J. (1977). The yamen and urban administration. In G. W. Skinner (Ed.), The city in late imperial China (pp. 353-390). Stanford, CA: Stanford University Press.

Will, P. E. (2008). Views of the realm in crisis: Testimonies on imperial audiences in the nineteenth century. Late imperial China, 29.1S, 125-159.

Will, P. E., \& Wong, R. B. (1991). Nourish the people: The state civilian granary system in China, 1650-1850. Ann Arbor, MI: Center for Chinese Studies, University of Michigan.

Wittfogel, K. A. (1957). Oriental despotism: A comparative study of total power. New Haven, CT: Yale University Press.

Xie, J. (2002). Xinxi chuandi yu xinhai geming [Information transmission and the revolution of 1911]. Journal of East China Normal University (Philosophy and Social Sciences) 4.

Yamamoto, H. (1993). Technological innovation and the development of transportation in Japan. Tokyo: United Nations University Press.

Yanagitani, K. (1985). Edo bakufu shirozumemai-sei no seiritsu [The establishment of Edo bakufu's strategic rice provisions]. Nihon Rekishi, 444, 38-57.

Yanagitani, K. (1989). Edo bakufu shirozumemai-sei no kino [The role of Edo bakuf'su strategic rice provisions]. Shigaku Zasshi, 69, 15-37.

Yoshida, N. (1991). Kinsei Kyodai Toshi no Shakai Kozo [The Social Structure of Metropolises in Premodern Japan]. Tokyo: Tokyo Daigaku Shuppan.

Zelin, M. (1984). The magistrate's tael: Rationalizing fiscal reform in eighteenth-century Ch'ing China. Berkeley: University of California Press.

Zelin, M. (2004). Economic freedom in late imperial China. In W. C. Kirby (Ed.), Realms offreedom in modern China (pp. 57-83). S, CAtanford: Stanford University Press.

Zhang, J. (2006). Water calamities and dike management in the Jianghan Plain in the Qing and the Republic. Late imperial China, 27(1), 66-108.

Zhang, Z. (1955). The Chinese gentry: Studies on their role in nineteenth-century Chinese society. Seattle, WA: University of Washington Press.

Zhang, Z. (1962). The income of the Chinese gentry. Seattle, WA: University of Washington Press. 